NBER WORKING PAPER SERIES

\title{
DO STOCK PRICES REALLY REFLECT FUNDAMENTAL VALUES? THE CASE OF REITs
}

\author{
William M. Gentry \\ Charles M. Jones \\ Christopher J. Mayer \\ Working Paper 10850 \\ http://www.nber.org/papers/w10850 \\ NATIONAL BUREAU OF ECONOMIC RESEARCH \\ 1050 Massachusetts Avenue \\ Cambridge, MA 02138 \\ October 2004
}

We thank David Geltner, Joe Gyourko, Peter Linneman, Steve Ott, Todd Sinai and seminar participants at the AREUEA Annual Meeting, the Columbia Business School, the Homer Hoyt Institute, the University of California at Berkeley, the University of Southern California, the University of Wisconsin, and the Wharton School for helpful comments. Dou-Yan Yang, Dimo Pramatarov, and Tobias Muhlhofer provided excellent research assistance. We are especially grateful to Jon Fosheim, Mike Kirby, and Green Street Advisors for providing crucial data used in this study. This paper was previously titled "Deviations between stock price and fundamental value for real estate investment trusts" and "REIT reversion: stock price adjustment to fundamental value." The views expressed herein are those of the author(s) and not necessarily those of the National Bureau of Economic Research.

(C2004 by William M. Gentry, Charles M. Jones, and Christopher J. Mayer. All rights reserved. Short sections of text, not to exceed two paragraphs, may be quoted without explicit permission provided that full credit, including $@$ notice, is given to the source. 
Do Stock Prices Really Reflect Fundamental Values? The Case of REITs

William M. Gentry, Charles M. Jones, and Christopher J. Mayer

NBER Working Paper No. 10850

October 2004

JEL No. G0, G12

\begin{abstract}
$\underline{\text { ABSTRACT }}$
Real estate investment trust (REIT) stock prices deviate substantially from net asset values (NAV). Using REIT data since 1990, we find large positive excess returns to a strategy of buying stocks that trade at a discount to NAV, and shorting stocks trading at a premium to NAV. Estimated alphas from this strategy are between $0.9 \%$ and $1.8 \%$ per month, with little risk. Trading costs and short-sale constraints are not prohibitive and the results strengthen when we control for differences in liquidity or the extent of institutional ownership. We find that some variation in P/NAV makes sense, as premiums are positively related to recent and future NAV growth. However, there appears to be too much volatility in $\mathrm{P} / \mathrm{NAV}$, giving rise to potential profits from short-term mean reversion. The closed-end fund literature has some similar findings on stock price deviations from fundamental value, but compared to closed-end funds REITs are much larger and have much higher insider and institutional ownership. These differences suggest that REIT premiums and discounts reflect more than just small investor sentiment, which is a common explanation of why closed-end fund prices deviate from their fundamental value.

William M. Gentry

Williams College

william.m.gentry@williams.edu

Charles M. Jones

Graduate School of Business

Columbia University

cj88@columbia.edu

Christopher J. Mayer

Columbia Business School

3022 Broadway, Uris Hall \#808

New York, NY 10025

and NBER

cm310@columbia.edu
\end{abstract}




\section{Introduction}

Do stock prices reflect fundamental values? This question has badgered the finance profession for decades. For most operating companies, or for the market as a whole, it is difficult to assess fundamental value. Fundamental value requires an assessment of future cash flows, along with an appropriate risk-adjusted discount rate.

In this paper, we look at a class of publicly traded operating companies where it is much easier to measure fundamental values: real estate investment trusts (REITs). REITs own and operate relatively illiquid real estate assets. However, these underlying assets can be valued fairly precisely by real estate professionals based on rental data, square footage, and transactions in comparable properties and locations, among other inputs. ${ }^{1}$ We have obtained estimates of NAV from Green Street Advisors, a buy-side investment advisor that regularly appraises the real estate holdings of major REITs. This enables us to look at REIT premiums and discounts to NAV, and whether these premiums and discounts can be used to generate profitable trading strategies.

We find that there are large cross-sectional differences in expected returns. It is profitable to buy REITs trading at a relative discount, and short REITs trading at a relative premium to NAV. The results are robust. Trading costs are low relative to excess returns. Short-sale constraints are not important, because most of the excess returns are on the long side. In fact, this strategy has better risk-return characteristics than momentum, widely considered the most persistent and unexplained excess return anomaly.

If REIT prices eventually revert toward NAV, what causes them to deviate in the first place? It turns out that premiums and discounts are associated with future changes in NAV, which suggests that stock prices have some predictive power for future fundamental value. This predictive power would justify modest departures from P/NAV $=1$. However, our meanreversion evidence on the predictability of returns implies that the stock market exhibits excess volatility for some reason - the premium or discount is too large.

\footnotetext{
${ }^{1}$ This methodology is not limited to REITs. In fact, analysts often use a similar methodology to assess the value of natural resource companies, multiplying the amount of proven reserves by the current and forecast price of the resource and subtracting off an estimate of extraction costs. While such estimates of fundamental value may be less precise than for real estate, nonetheless they provide an attractive benchmark for valuation that is used in many contexts.
} 
In some ways, REITs are similar to closed-end funds. Both are investment trusts, and in both asset types fundamental value can be assessed by valuing the underlying assets. Thus, our results are closely related to the literature on closed-end fund prices. Closed-end funds pose a similar puzzle: most closed-end funds hold publicly traded securities, with net asset values (NAVs) that are published weekly, yet their share prices wander considerable distances from NAV. It is impossible to do justice here to the complete literature on closed-end funds; Dimson and Minio-Kozerski (1999) provide a useful survey. There are reasons to expect prices to differ from NAV, including expected future trading and management costs (Malkiel, 1977), expected manager performance (Chay and Trzcinka, 1999), tax liabilities and tax timing (Brickley, Manaster, and Schallheim, 1991), and market segmentation (Bonser-Neal, Brauer, Neal, and Wheatley, 1990). However, most of these effects are invariant through time. It is much more difficult to account for the time-variation in discounts and premiums without a behavioral explanation.

Lee, Shleifer, and Thaler (1991) claim that discounts on closed-end funds reflect (individual) investor sentiment. They point out that closed-end funds are mainly held by individuals and are largely shunned by institutional investors. In contrast, REIT institutional ownership is quite high, with institutions owning about half of REIT shares, and we find that the predictability of REIT returns is weakly increasing in the level of institutional ownership. Both these facts suggest that discounts and premiums on REITs are not solely due to investor sentiment, unless institutions themselves are subject to the same kinds of sentiment.

This paper is also related to empirical studies on how specific fundamental information is incorporated into prices. For example, Womack (1996) finds that stock prices react strongly and quickly to changes in analyst recommendations, though prices continue to drift in the same direction over the next several months. In contrast, for REITs, we find that information incorporation is surprisingly slow. When NAVs are released to clients, they can immediately trade on the information. A week later, less than half of the information has found its way into price.

The paper is organized as follows. Section 2 provides a quick overview of real estate investment trusts. Section 3 details the Green Street appraisal data that we use and discusses reasons why REIT share prices might depart from the assessment of net asset value. Section 4 provides the main results, based on sorting REITs into portfolios based on their ratio of price to 
NAV. Section 5 provides a number of robustness tests and considers transaction costs and other impediments to a trading strategy based on mean reversion. Section 6 considers alternative risk factors that might account for the profits identified here, and Section 7 shows that variation in $\mathrm{P} / \mathrm{NAV}$ predicts future NAV growth, indicating that the market is able to differentiate between fast-growing and slow-growing REITs. Section 8 draws some parallels to the closed-end fund literature but also highlights the important differences. Section 9 concludes.

\section{Background on REITs}

With certain key tax-related exceptions, REITs are similar to other corporations. Like other corporations, REITs initiate operations by raising capital from external markets and investing the capital in operating assets. The benefit of qualifying as a REIT is avoiding the double taxation of equity-financed investment. Unlike regular corporations, REITs receive an annual tax deduction for dividends paid out to shareholders. REITs often distribute all of their taxable income to shareholders each year, which eliminates the corporate tax altogether.

To qualify as a REIT, among other things, a firm must meet certain asset and income tests that set minimum levels of real estate activity to prevent REITs from using their taxadvantaged status in non-real-estate activities. REITs must earn at least 75 percent of their income from real estate-related investments and 95 percent of their income from these sources as well as dividends, interest and gains from securities sales. In addition, at least 75 percent of their assets must be invested in real estate, mortgages, REIT shares, government securities, or cash. While older REITs were often passive investors, several changes in tax rules in the late 1980s allowed REITs to actively manage their assets during the 1990s. Although some REITs invest in real estate mortgages, we restrict our focus to publicly traded equity REITs, which primarily invest in rental properties.

In addition to the asset and income tests, tax law requires REITs to pay out a minimum percentage of their taxable income as dividends each year. For most of our sample period, this percentage was 95 percent; however, tax changes in 2000 reduced the minimum percentage to 90 percent. This distribution requirement is based on taxable income rather than financial reporting income. Despite this requirement, REITs have some discretionary cash flow because operating cash flow typically exceeds taxable income, especially since depreciation allowances reduce taxable income but not cash flow. In general, however, the distribution requirement limits 
REITs' ability to finance investment with internally generated funds, so they rely more heavily on secondary equity issues than do regular corporations.

\section{Data Description}

The relatively straightforward nature of REITs' assets (compared to industrial firms) leads many analysts to value REITs by appraising their properties and other assets. The key explanatory variable for our empirical work is one set of these appraisals from Green Street Advisors, Inc. Green Street computes Net Asset Value (NAV) based on the estimated market value of each REIT's assets by assessing the value of the major properties of a REIT (plus other miscellaneous assets) and subtracting the liabilities of the REIT. Green Street's goal is to compare the market value of the REIT's common stock with the market value of the underlying assets (after adjusting for other ownership claims). They use these estimates to advise clients (typically large institutional investors) on selecting REITs as investments.

Several factors motivate using the Green Street NAV estimates. Industry observers and participants almost uniformly agree that Green Street produces the most careful and accurate estimates in the REIT industry. It is the only analyst firm to have a consistent set of estimates prior to 1996. Green Street focuses exclusively on real estate firms and each of its analysts follows only a few firms. These analysts specialize by type of property and compute NAV by determining the fair market value of each property owned by a REIT, often visiting larger

properties. Finally, Green Street performed no investment banking functions for REITs over our sample period, so it is immune from the potential conflicts of interest that may impact the research of investment banks that underwrite securities.

We use the Green Street estimates of NAV as a measure of the underlying value of a REIT's assets. An important question to keep in mind is whether the Green Street estimates are public information available to all investors or private information that is only available to the managers of the firm and certain private investors. We believe that the Green Street information is somewhere between public information and purely private information. The existence of Green Street NAVs is well-known to the institutional investor community. However, the NAVs themselves are available to institutions in return for commission trading business; Green Street does not release the information to non-clients. 
We use data on Green Street NAVs from January 1990 through December 2003. The number of equity REITs expanded over the course of our sample period, from 58 REITs with $\$ 5.5$ billion of total market capitalization in 1990, to 144 REITs with a total market capitalization of over \$205 billion by the end of 2003. All of the growth in the number of REITs came between 1990 and 1995. Since then, on net, the industry has been characterized by consolidation and expansion of existing REITs. ${ }^{2}$ Our sample matches Green Street's coverage of REITs, which expanded in line with the overall sector. At the beginning of the sample, Green Street covers 16 REITs. By December 2003, there are 59 REITs in our sample. Though Green Street covers about $41 \%$ of all REITs, the firm covers almost all large REITs and many smaller ones. Our sample reflects about $73 \%$ of the total capitalization in the sector.

From 1990 through 1993, Green Street released NAVs quarterly. Beginning in 1994, Green Street released NAVs at the end of every month. Until 2000, Green Street reports were mailed to clients approximately five days before the end of the month in order to ensure arrival by the end of the month. Beginning in 2000, Green Street delivered its research electronically, and NAV data became available to all clients after the close of trading on the first trading day of the month.

Our key explanatory variable is P/NAV, the ratio of the REIT's month-end share price (taken from data from the University of Chicago's Center for Research in Security Prices (CRSP)) to Green Street's estimate of the REIT's NAV. Over our sample period, the mean (median) share-price-to-NAV ratio is 1.03 (1.01). While the central tendency of this ratio is close to one, there is substantial time-series and cross-sectional variation. Figure 1 plots the 25 th percentile, median, and 75th percentile price-to-NAV ratio by month for 1994-2003. The interquartile range for $\mathrm{P} / \mathrm{NAV}$ is typically about 0.20 , though it has narrowed slightly over time.

It is important to emphasize that in this paper we are most interested in cross-sectional differences in P/NAV. Nevertheless, it is clear from Figure 1 that the average REIT P/NAV also varies over time, with the median value above 1.20 for all of 1997 and below 0.9 for most of 2000. Clayton and MacKinnon (2003) argue that this industry-wide component represents a form of investor sentiment for REITs. Aggregate P/NAV appears to be stationary and meanreverting, which implies that there might also be a successful trading strategy that emphasizes market timing rather than picking stocks from the cross-section. However, forecasting

\footnotetext{
${ }^{2}$ Industry statistics are from the National Association of Real Estate Investment Trusts' website at www.nareit.org.
} 
regressions indicate that average $\mathrm{P} / \mathrm{NAV}$ does not reliably forecast future aggregate REIT returns, so we focus on the cross-section in the rest of the paper. ${ }^{3}$

Should P/NAV = 1 for REITs? Of course, real estate appraisals are imperfect, so we would never expect this to hold identically through time, but an average P/NAV $=1$ is clearly the benchmark for a counterfactual frictionless world. Given the straightforward nature of REIT operations, REIT price-to-NAV has significant advantages over market-to-book ratios for other operating firms, a point emphasized by Gentry and Mayer (2003) and Capozza and Seguin (2003). However, there are potential reasons for an equilibrium P/NAV ratio that differs from one. For example, Gentry, Kemsley and Mayer (2003) argue that a REIT's price should be less than its NAV if its tax basis in its properties is below market value; they find evidence consistent with this prediction. A REIT might also trade below its NAV if there are additional costs associated with operating a REIT versus alternative organizational forms for holding real estate, including the costs of potential conflicts of interest between managers and investors.

One can, however, make a case that the P/NAV ratio can be above one. If a REIT has good management, and that management does not appropriate all the economic rents that it generates, then investors will be willing to bid the REIT share price up above NAV. Similarly, if costs of capital are lower in the public markets, perhaps due to the benefits of liquidity, then prices might be above NAV.

However, these arguments are mostly about average levels of P/NAV. As in the case of closed-end funds, it is much harder to tell a coherent story of why discounts and premiums should revert, or why discounts should move to premiums. To put it another way, in an efficient market, if NAV is known to a large set of investors, it should be impounded into prices. P/NAV should not predict the cross-section of REIT returns unless it is associated with some sort of priced risk. In the next section, we show that there is indeed substantial mean reversion. High P/NAV stocks have low subsequent returns, and low P/NAV stocks have high subsequent returns, even after adjusting for known risk factors.

\footnotetext{
${ }^{3}$ To be precise, we regress $r_{t, t+t}$, the value-weighted return on our sample of REITs between time $t$ and time $t+j$, on an intercept and the value-weighted P/NAV at time $t$. When $j=12$ months, the slope coefficient is -0.34 and the $\mathrm{R}^{2}$ is $11.4 \%$. The time series is very short, only about 10 years, and the predictor variable is very persistent (with a monthly autocorrelation of 0.95 ), which together suggest low statistical power. Simulations based on Stambaugh (1999) confirm that the estimated slope coefficient is indistinguishable from zero for all forecasting horizons $(\mathrm{p}=$ 0.545 at the 1 -year horizon).
} 


\section{Methodology and results}

Each month, we consider all REITs for which Green Street reports an NAV per share. These REITs are sorted into quartiles based on share price divided by NAV. In the early part of the sample, NAVs were available to clients by the end of the month. In the latter part of the sample, NAVs were posted at the close of the first trading day of the month. Thus, to ensure that the NAVs are in an investor's information set, we examine returns beginning on the second trading day of the month. We examine value-weighted returns over the next day, week, month, and quarter.

Summary statistics on these portfolios, for the end of 2001, can be found in Table 1. REITs in the lowest P/NAV quartile trade at slight discounts to NAV. These stocks have an average market capitalization of $\$ 1.1$ billion at the end of 2001, and insider ownership averages $15 \%$ of shares outstanding. These stocks trade an average of just over 140,000 shares per day, and the average proportional bid-ask spread on these low P/NAV stocks is $0.7 \%$. REITs in the highest P/NAV quartile tend to be considerably larger, with an average market capitalization of $\$ 3$ billion at the end of 2001. Perhaps as a result of this, they tend to have slightly lower inside ownership (11\% of shares outstanding), and they tend to be slightly more liquid, with an average proportional bid-ask spread of $0.5 \%$ and average trading volume of 423,263 shares.

Over the next several months, low P/NAV stocks substantially outperform high P/NAV stocks. For the month after sorting into quartiles, stocks in the lowest P/NAV quartile have a value-weighted average return of $1.08 \%$ per month, while stocks in the highest P/NAV quartile have an average monthly return of $-0.04 \%$. Figure 2 provides a comparison of the cumulative returns of the value-weighted average returns of the lowest P/NAV quartile (Quartile 1) and the highest P/NAV quartile (Quartile 4) for roughly three months (75 trading days) following the sort date. In the first month after sorting on P/NAV, the average return of the low P/NAV REITs is about $1.0 \%$ but the average return of the high P/NAV REITs is roughly zero. This difference accumulates fairly steadily over the first 20 days after sorting the firms. After this initial difference in returns, the portfolios have roughly similar performance so that by the end of the 75 trading day period, the difference in the average return on the two portfolios is still roughly one percentage point.

These average return differences are substantial but could just be compensation for risk. To adjust for known systematic risk factors, we take a standard time-series approach originally 
introduced by Black, Jensen and Scholes (1972) in testing the CAPM. We also use the risk factors introduced by Fama and French (1993). ${ }^{4}$

All stocks in a quartile are aggregated into a single value-weighted portfolio, and monthly or quarterly returns on portfolio $i$ are projected on contemporaneous factor returns:

$$
\mathrm{r}_{\mathrm{it}}=\alpha_{\mathrm{i}}+\beta_{\mathrm{i}}^{\mathrm{RMRF}} \mathrm{RMRF}_{\mathrm{t}}+\beta_{\mathrm{i}}^{\mathrm{SMB}} \mathrm{SMB}_{\mathrm{t}}+\beta_{\mathrm{i}}^{\mathrm{HML}} \mathrm{HML}_{\mathrm{t}}+\varepsilon_{\mathrm{it}} \text {, }
$$

where RMRF (return on the market portfolio above the risk free rate of return) is the excess return over the T-bill rate of the value-weighted portfolio of all CRSP stocks, SMB (small minus big) is a size factor, defined as the return on small firms in excess of the return on big firms, and HML (high minus low) is the value factor, defined as the return on high book-to-market stocks less the return on low book-to-market stocks. All three factors are taken from Ken French's website. REIT portfolio returns, $r_{i t}$, are excess returns over the T-bill rate. The intercept in this regression, or alpha, is the average excess return on the portfolio after adjusting for these three known risk factors.

As noted above, since Green Street expanded its coverage over the course of the sample period, the number of REITs in each quartile increases over time. This affects estimation of the time-series regression equation since fewer REITs means noisier estimates of the factor loadings and larger residual variance, rendering ordinary least squares techniques inefficient. To correct for this, we weight by the number of REITs in the portfolio in a given period.

New Green Street data become available every month, and we form portfolios and calculate returns every time NAV data become available. At the quarterly horizon, forming portfolios every month creates overlap across adjacent observations. Newey-West (1987) standard errors with two lags are used to adjust for this overlap.

For monthly and quarterly returns, we also estimate a single-factor CAPM version of this model that includes the market factor (RMRF) as the only risk factor. For returns one day and one week after portfolio formation, we estimate only the single factor version, because daily and weekly SMB and HML realizations are not readily available.

The results are in Table 2a. Both the intercepts and slope coefficients are noteworthy. All four quartile portfolios load similarly on the three Fama-French factors, suggesting a common industry-wide pattern to returns. All have fairly modest loadings on the market

\footnotetext{
${ }^{4}$ Relevant applications of this methodology include Carhart (1997) to mutual fund performance and Barber et al. (2001) to consensus analyst recommendations, among many others.
} 
portfolio, with a range of 0.28 to 0.47 for monthly returns. REIT returns seem to behave like returns for small firms; all four quartiles load positively and reliably on the small firm factor, with coefficients between 0.23 and 0.45 . Finally, REITs load positively on the value factor, with coefficients ranging from 0.24 to 0.33 , which is sensible since REITs generally have large dividends and limited growth opportunities.

The alphas in Table 2a confirm the simple average return differences noted above. We continue to focus first on monthly returns. In the single factor model, low P/NAV REITs (quartile 1) have a statistically significant positive alpha of $0.84 \%$ per month, or more than $10 \%$ on an annualized basis. REITs with a high P/NAV (quartile 4) have a slightly negative estimated alpha of $-0.17 \%$ per month, which is statistically indistinguishable from zero. Alphas in the Fama-French three-factor specification are somewhat lower, but the difference across portfolios is quite similar to the results from the single-factor model. Low P/NAV REITs (quartile 1) have an estimated alpha of $0.66 \%$ per month that is statistically different from zero at the 95 percent confidence level, while REITs in quartile 4 have an estimated alpha of $-0.28 \%$.

As a stronger test of predictability of returns based on P/NAV, Table $2 \mathrm{~b}$ examines the returns on portfolio 1 minus the returns on portfolio 4. This corresponds to a trading strategy that buys low P/NAV stocks and shorts an equal dollar amount of high P/NAV stocks. If there is a factor common to all REITs, this strategy should eliminate exposure to the industry factor. The results indicate that the zero-investment portfolio hedges out much of the factor risk. Again we focus first on the monthly returns to this trading strategy. The simple CAPM beta is only 0.18 , and the Fama-French factor loadings are similarly small (0.22 and 0.086). However, the alphas are economically large and statistically significant at the 95 percent confidence level. For the single-factor model, the estimated alpha is $1.0 \%$ per month and for the three-factor model the estimated alpha is $0.94 \%$ per month, more than $11 \%$ per year.

One motivation for examining returns at various horizons is to assess how quickly REIT prices incorporate the Green Street information. Consistent with the unadjusted return data presented in Figure 2, the answer seems to be that prices adjust quite slowly. Consider for example the return differences of Table $2 \mathrm{~b}$. The one-month CAPM alpha is $1.0 \%$. One day after publication of the NAVs, the estimated alpha of $0.097 \%$ is one-tenth the size of the one-month estimate. After one week, less than half of the information has been incorporated, with an 
estimated alpha of $0.45 \%$. Thus, it appears that excess returns persist for some time, giving institutions ample opportunity to trade on the information.

Most of the information, however, appears to be impounded within one month. Over a three-month horizon, the CAPM estimated alpha on the long-short strategy is $1.0 \%$, which is the same as over the one-month horizon; for the three-factor model, the point estimate of alpha over the three-month horizon $(0.77 \%)$ is slightly smaller than the estimated alpha over the one-month horizon $(0.94 \%)$. To put it another way, profits to this trading strategy do not continue to accrue after the information is one month old. Furthermore, in both cases, the standard error of the estimated alpha for the three-month horizon is almost triple the standard error from the onemonth horizon, suggesting the precision of the estimated excess return falls as the horizon expands.

The trading strategies so far consider only cross-sectional variation in P/NAV. However, Figure 1 demonstrates that the average REIT P/NAV varies over time. Thus, it might be possible to exploit this time-series mean reversion by looking at absolute levels of P/NAV rather than just relative rankings. To investigate this, we set arbitrary breakpoints for P/NAV at $90 \%, 100 \%$, and $110 \%$, and sort REITs into portfolios based on these breakpoints. REITs are not always evenly distributed across these portfolios. In fact, in some months some of the portfolios are empty. For example, portfolio 4, which consists of REITs with price greater than $110 \%$ of NAV, has stocks in it for only 90 out of 120 months.

Once these portfolios are formed based on the premium or discount to NAV, the same econometric approach is taken. Returns are regressed on either a single market factor or the three Fama-French risk factors and the regression is weighted by the number of REITs in the portfolio for that period.

Returns on these portfolios are summarized in Table 3a. Again, REITs with low P/NAV have the highest subsequent returns. REITs with P/NAV less than $90 \%$ are in portfolio 1 , and these stocks have an average CAPM alpha of $1.30 \%$ in the next month. The alphas decline monotonically across portfolios, and high P/NAV REITs in portfolio 4 have an insignificant average CAPM alpha of $-0.22 \%$ in the following month. As in the earlier analysis, the alphas from the three-factor model yield a similar cross-sectional pattern to that of the alphas from the single-factor model. 
Again, the cross-sectional patterns suggest a long-short strategy that buys REITs with low P/NAV and shorts REITs with high P/NAV. We examine portfolio 1 returns minus portfolio 4 returns, and for simplicity we include only those months where both the long and the short portfolio are non-empty. This yields 90 monthly returns out of a possible $120 .^{5}$ Table $3 \mathrm{~b}$ documents that this strategy has very high returns and little systematic risk. Focusing on onemonth returns, the estimated alpha from the single-factor model is $1.8 \%$ per month $(21 \%$ annualized) and the estimated alpha from the Fama-French model is $1.7 \%$ per month (20\% annualized). Both of these estimates are statistically distinguishable from zero at the 95 percent confidence level. Adding the time series dimension to the predictability of returns (instead of focusing solely on the cross-sectional patterns of returns as we did in Table 2) increases the magnitude of the estimated excess returns by over 50 percent.

As with the previous results, the evolution of the estimated alpha over time is fairly slow. One day after the NAVs are published, the long-short alpha is $0.19 \%$, rising to only $0.74 \%$ after one week, less than half of the one-month number. Much of the information, though not all of it, appears to be incorporated within one month of publication. The three-month CAPM estimated alpha on the zero-investment strategy is $2.1 \%$ per month, while the three-month Fama-French estimated alpha remains $1.7 \%$.

\section{Implementation and robustness}

Are there any barriers to implementing these strategies? While these excess returns are large, REITs are not generally large-cap stocks, suggesting that the trading costs of implementing these strategies could be large. Our sample, which consists of the largest REITs, now has an average market capitalization of less than $\$ 2$ billion. Thus, it is important to get a sense of the transaction costs involved in trading REIT shares. In addition, as noted by Shleifer and Vishny (1997) and others, there may be short-sale constraints and other impediments to conducting the kinds of strategies considered here. These transaction costs put limits on investors' ability to capture arbitrage profits.

To investigate the effects of trading costs, we first calculate average bid-ask spreads on the REITs in our sample, using the NYSE's TAQ database. The average proportional quoted

\footnotetext{
${ }^{5}$ In Table 3b, we include results from portfolios 1 and 4 based on the subsample of 90 periods in which both the high and low portfolios have some REITs. As expected, these results are quite similar to the results reported in Table 3 a that use slightly larger samples.
} 
spread ranges from $0.5 \%$ for quartile 4 (the high P/NAV quartile) to $0.7 \%$ or $0.8 \%$ for lower $\mathrm{P} / \mathrm{NAV}$ stocks. These are quite large relative to spreads for actively-traded stocks (such as IBM), but they are not prohibitive. Specifically, these spreads are on the order of half of the monthly alphas to the long-short strategy, so they do not eliminate the excess returns. In fact, quoted spreads are typically biased upward as an estimate for trading costs, because many trades take place inside the spread. Given that REIT prices adjust slowly to the Green Street information, it might also be possible for an institution to acquire a position quite passively over time, at considerable trading cost savings. In any case, it appears that the point estimates of excess returns far exceed the likely trading costs.

As a more direct specification check, we exclude the least liquid REITs and replicate the return analysis. By excluding the least liquid REITs that presumably have the highest transaction costs, we focus our estimation on REITs for which investors are most likely to be able to profitably arbitrage the predictability of REIT stock returns based on information about P/NAV. Each period, before we sort REITs into quartiles, we exclude one-fourth of the REITs with the widest proportional bid-ask spreads. We then sort REITs into quartiles based on P/NAV and replicate the time-series regressions. The results for the one-month returns are in the first two columns of Table $4 \mathrm{a}$ and $4 \mathrm{~b}$. If anything, the results are slightly stronger. ${ }^{6}$ Using the onefactor model, the long-short strategy generates an estimated alpha of $1.1 \%$ per month, or $13 \%$ per year and a similar estimated alpha for the three-factor model.

Another concern is that it may be difficult to short REITs with high P/NAV. First, it is important to point out that economically large alphas are possible even without shorting REITs. Table $3 \mathrm{~b}$ indicates that simply buying REITs with P/NAV below $90 \%$ provides a monthly alpha of $1.1 \%$, or over $13 \%$ per year, which is almost two-thirds the hedged portfolio alpha of $1.8 \%$ per month. The risk of this strategy can be reduced considerably by shorting a broad stock market index and/or a value-oriented basket or index, either of which is easy and cheap to accomplish using exchange-traded funds or stock index futures.

Despite these high alphas on the long side of the trade, we still want to explore the shortsale characteristics of the high P/NAV firms. Ideally, we would like to have a panel of rebate rates such as that collected by Geczy, Musto, and Reed (2002), D’Avolio (2002), or Jones and

\footnotetext{
${ }^{6}$ Excluding the less liquid REITs increasing the predictability of returns is consistent with arbitrage activity playing a role in the price reversals suggested by the estimated excess returns.
} 
Lamont (2002), since rebate rates are perhaps the most important direct measure of the cost of shorting. However, rebate data for our sample period are proprietary and difficult to procure. As a second-best alternative, we collect short interest data on the REITs in our sample. We find that short interest in these REITs is fairly substantial, and it appears that some market participants may be engaging in the kinds of trading strategies discussed here. For example, based on data from the end of 2001, the lowest P/NAV quartile has short interest equal to 2.95 days of average trading volume. In contrast, the highest P/NAV quartile has short interest representing 7.02 days of average trading volume. These numbers are similar in magnitude to aggregate short interest, which is about five days of overall trading volume for NYSE stocks as of the end of 2002. Finally, we know that institutional ownership of REITs is about 50\%. Shares held by institutions are much more likely to be available for lending via custodians, so it seems likely that most REITs can be shorted without prohibitive costs.

\section{Missing risk factors?}

Figure 3 plots the time-series of the returns to the basic long-short strategy. The strategy has a positive return in almost all months, but there are occasional losses. However, the periods with losses on the trading strategy do not seem obviously related to any known risk factor, based on the time-series plot. Nevertheless, it is possible that these returns are related to some sort of systematic risk.

For example, perhaps this strategy provides compensation for illiquidity, an effect originally identified in stock returns by Amihud and Mendelson (1986). This seems possible, given the Table 1 evidence that high-priced, low-alpha stocks are more liquid than the REITs with low P/NAV. The less liquid stocks (which have low P/NAV, since being illiquid may reduce the share price) may have high returns to compensate for risks associated with illiquidity rather than because they have a low P/NAV. In the sensitivity analysis above, we excluded the least liquid REITs to confirm that transaction costs associated with illiquidity are not an impediment to arbitrage profits. We now turn to whether illiquidity could affect the analysis in a different way - by creating a spurious relationship between observed returns and P/NAV.

To investigate the possibility that illiquidity is a priced risk factor which creates a spurious relationship between returns and P/NAV, we adopt a double sort method. First, we sort based on bid-ask spreads, as a measure of liquidity; second, we sort on P/NAV. The resulting 
portfolios have approximately the same distribution of bid-ask spreads, but differ markedly in their average P/NAV. Specifically, we sort all REITs in a given month by their proportional bidask spreads. The four REITs with the smallest spreads are then sorted by P/NAV. The lowest $\mathrm{P} / \mathrm{NAV}$ of the four goes into quartile 1 , the next into quartile 2 , and the highest P/NAV of the four is assigned to quartile 4 . We then repeat this assignment exercise for the four REITs with the next-smallest spreads. This process continues until all REITs are assigned to P/NAV portfolios.

We then look at the performance of these portfolios using the same econometric methodology applied earlier. The results for the analysis of one-month returns are in the last two columns in Tables $4 \mathrm{a}$ and $4 \mathrm{~b}$. If anything, the results become stronger. Monthly risk-adjusted excess returns on portfolio 1 (low P/NAV) are 1.2\% higher than for portfolio 4 (high P/NAV). As before, these return differences are statistically and economically different from zero. Thus, our basic results do not seem to be driven by liquidity differences.

In results not reported, we also look at a number of other possible ways that low P/NAV REITs might differ from those with high P/NAVs. Based on data from SNL Securities, we find that returns are completely unrelated to the amount of leverage employed by the REIT and insider ownership.

\section{P/NAV as a predictor of fundamentals}

The mean-reversion in P/NAV is strong and robust. But why does P/NAV vary? One possibility is that the variation is completely unrelated to fundamentals so that stock prices may deviate from fundamental value purely for idiosyncratic reasons. However, another possibility is that $\mathrm{P} / \mathrm{NAV}$ is just like price-earnings $(\mathrm{P} / \mathrm{E})$ ratios: firms where NAV is growing at an abovemarket rate should carry higher multiples. This possibility would predict that differences in P/NAV would predict future growth in NAV (or earnings) with higher P/NAV REITs having faster growth in NAV per share. Of course, it is a bit hard to imagine NAVs growing at abovemarket rates, since they are supposed to reflect market values of real estate assets that are themselves based on discounted cash flows. However, perhaps some managers are particularly skilled at doing deals, and are able to increase their REIT's NAV faster than others in the industry. Alternatively, perhaps Green Street NAVs adjust with a lag, because of the effort required to update them in a timely fashion. 
To put it precisely, if P/NAV is stationary, which it appears to be, then it must either predict future returns or future changes in NAV. That is, if $\mathrm{P} / \mathrm{NAV}$ is high, either future expected returns are low, expected NAV growth is high, or both. ${ }^{7}$ In fact, variation in P/NAV could be completely consistent with an efficient market with constant expected returns if NAV changes were predictable. To investigate this, we look to see whether the cross-section of $\mathrm{P} / \mathrm{NAV}$ is associated with cross-sectional variation in future NAV growth. Since Green Street releases NAVs every month, it is possible to define an NAV return in the usual fashion for monthly and quarterly returns:

$$
\mathrm{R}_{\mathrm{it}}{ }^{\mathrm{NAV}}=\left(\mathrm{NAV}_{\mathrm{t}}+\mathrm{D}_{\mathrm{t}}\right) / \mathrm{NAV}_{\mathrm{t}-1}
$$

where $D_{t}$ is the dividend paid on the REIT share in period t.

We examine future NAV returns in the same econometric framework we used for stock returns. We sort REITs into quartiles based on their P/NAV in month $t-1$, form value-weighted portfolios, and then control for risk factors that might influence the next month's NAV return:

$$
\mathrm{r}_{\mathrm{it}}^{\mathrm{NAV}}=\alpha_{\mathrm{i}}+\beta_{\mathrm{i}}^{\mathrm{RMRF}} \mathrm{RMRF}_{\mathrm{t}}+\beta_{\mathrm{i}}^{\mathrm{SMB}} \mathrm{SMB}_{\mathrm{t}}+\beta_{\mathrm{i}}^{\mathrm{HML}} \mathrm{HML}_{\mathrm{t}}+\varepsilon_{\mathrm{it}},
$$

where the NAV return is an excess return over the T-bill rate and we again weight by the number of REITs in the portfolio for a given month.

The results are in Table 5a. Note first that NAV changes do not covary much with the Fama-French factors. Factor loadings are all very small. However, the estimated alphas indicate that P/NAV contains a great deal of information about future growth in fundamentals. REITs with low P/NAV (quartile 1) experience low NAV returns in the next month on the order of $-0.4 \%$, while REITs with high P/NAV (quartile 4) see excess NAV returns of about $1.0 \%$ in the next month. The difference between the future NAV returns on the two quartiles is about $1.4 \%$ per month (see Table 5b). This estimated alpha is slightly larger than the estimated alpha for the one-month long-short strategy of investing in REIT stocks of $1.0 \%$ per month.

By this metric, slightly more than half of the P/NAV variation reflects the market's ability to forecast changes in NAV and slightly less than half of the P/NAV variation meanreverts out through stock price changes in the next month. One explanation is that the market is able to determine which REITs or which sectors will, say, appreciate fastest, but the market goes overboard in marking up the fast-growth REITs, and share prices rise too much.

\footnotetext{
${ }^{7}$ This is an exact analog to variation in the dividend-price ratio discussed by Campbell and Shiller (1988) and in Chapter 20 of Cochrane (2001). If dividend yields are stationary, then a lower dividend yield indicates either higher expected dividend growth, lower expected returns in the future, or both.
} 
We also examine the longer horizon predictability of changes in NAV per share by estimating the same model using returns with a three-month horizon. Unlike the results for the predictability of stock returns, the estimated alphas for the three-month horizon are larger than the estimated alphas for the one-month horizon. For example, the estimated three-month alpha for the long-short strategy from the one-factor model is $-3.2 \%$, which is more than double the estimated alpha of $-1.4 \%$ for the one-month horizon. That is, over the next three months and after controlling for factor risks, NAVs for the top P/NAV quartile of REITs grow 3.2\% more than NAVs for the bottom quartile. Perhaps Green Street analysts are adjusting NAVs with a

lag. Perhaps the stock market has additional value-relevant information that is not used by the Green Street analyst in assessing NAV.

The NAV-return results are similar when we use fixed P/NAV breakpoints to sort REITs; these are reported in Tables $6 \mathrm{a}$ and $6 \mathrm{~b}$. The difference in NAV growth between quartile 1 and quartile 4 in the next month is $1.5 \%$ depending on the risk adjustment used. This is almost identical to the results from the standard cross-sectional sort based on relative P/NAV.

\section{REITs vs. closed-end funds}

As mentioned in the introduction, many researchers have used closed-end mutual funds as a window into whether stock prices reflect fundamental value. Our results for REITs suggest that stock prices deviate from fundamental value but that these differences change over time due to mean reversion in stock prices and predictable growth in NAV. These results have parallels in the closed-end fund literature. For example, our result on the excess returns to investing in REITs based on P/NAV is similar to results reported by Thompson (1978) and Pontiff (1995). Moreover, similar to our result that P/NAV predicts future changes in the NAV of REITs, Chay and Trzcinka (1999) show that P/NAV predicts subsequent NAV changes for closed-end funds (see also Swaminathan, 1996).

While REIT premiums and discounts seem to behave similarly to closed-end fund discounts, it is unlikely that some of the explanations for closed-end fund discounts or premiums will also apply to REITs due to differences in the characteristics of REITs (and REIT owners) compared to closed-end funds (and their owners). Put differently, stock price deviations from NAV and the predictability of future returns and NAV growth can exist in an environment that differs considerably from the closed-end fund environment. 
Lee, Shleifer, and Thaler (1991) argue that the time-varying closed-end fund discount or premium depends on investor sentiment about equity markets. Since closed-end funds are primarily held by individuals, their prices are bid up relative to NAV when individuals have a favorable opinion about the prospects of the stock market, but prices will fall (relative to NAV) when individual investors are pessimistic about the stock market. Overall, this explanation is less convincing for REITs since institutional ownership plays an important role for REITs. Approximately half of REIT shares are held by institutions, so one would expect that individual investor sentiment has a smaller role for determining REIT prices. However, as reported in Table 1, institutional ownership is lower for the highest P/NAV quartile than for the lowest $\mathrm{P} / \mathrm{NAV}$ quartile (46\% compared to $54 \%$ ) so it is possible that individual investor sentiment does play some role in REIT pricing. ${ }^{8}$

As a further test of the Lee, Shleifer, and Thaler individual investor sentiment hypothesis, we return to our double sorting methodology to create portfolios that differ in P/NAV but have a relatively similar degree of institutional ownership. Institutional ownership is reported on a quarterly basis, so we use the most recent percentage of institutional ownership to sort REITs into four quartiles. Next we sort each institutional ownership quartile by P/NAV and examine returns for the various P/NAV quartiles. Consistent with our earlier findings, the monthly excess return $(\alpha)$ for quartile 1 is $1.3 \%$, versus $-0.3 \%$ for the fourth quartile. The difference between quartiles 1 and 4 is highly statistically significant and, if anything, larger than our base results from Table 2. These findings strongly suggest that the mispricing REITs associated with P/NAV is not due to investor sentiment unless institutions also exhibit a similar degree of investor sentiment.

Pontiff (1996) argues that higher dividends lead to smaller mispricings on closed-end funds, because the dividends reduce the holding costs of the arbitrage strategy. Put differently, the security can be mispriced, but the dividend is not since investors receive the full value of the dividend. Pontiff finds support for this hypothesis using data for closed-end funds from 1965 to 1985. Given the size of the typical REIT dividends, this hypothesis would predict that REIT prices would have only small deviations from NAV, which is inconsistent with our results.

\footnotetext{
${ }^{8}$ While the univariate comparison suggests that individuals (i.e., non-institutions) own a larger share of high P/NAV REITs relative to low P/NAV REITs, the REITs in the different P/NAV quartiles also vary along other dimensions, most notably total size.
} 
Coles, Suay, and Woodbury (2000) report that closed-end fund premiums are positively correlated with insider ownership. However, REITs have insider ownership (see Table 1) which is on the order of ten times the insider ownership of closed-end funds. Despite this substantial insider ownership, a substantial number of REITs often sell at a discount.

Another major difference between REITs and closed-end funds is that REITs might be more volatile than closed-end fund in terms of deviations from $\mathrm{P} / \mathrm{NAV}=1$. There are two possible explanations for this difference, and both explanations arise because REITs own and operate real assets. First, this probably means that REIT NAV estimates are noisier than their closed-end fund counterparts, and this might account for REITs' relatively large deviations from $\mathrm{P} / \mathrm{NAV}=1$. Second, in contrast to closed-end funds, it is impossible to conduct arbitrage per se on a mispriced REIT. The underlying REIT assets cannot be shorted, so a perfect hedge is not possible. This means that any arbitrageur takes on basis risk with any hedge. While we have identified a successful long-short strategy that earns economically and statistically significant alphas, these alphas are not riskless.

\section{Conclusions}

In this paper, we show that REIT share prices deviate from their NAVs, where NAVs are estimated by Green Street Advisors, a well-respected buy-side research firm. Using REIT data since 1990, we find large positive excess returns to a strategy of buying stocks that trade at a discount to NAV, and shorting stocks trading at a premium to NAV. Estimated alphas are between $0.9 \%$ and $1.8 \%$ per month. There is little systematic risk to this strategy, because it hedges out any REIT industry factor that might exist. Trading costs and short-sale constraints are not prohibitive, and these alphas do not appear to be related to liquidity.

We find that some variation in P/NAV makes sense, as premiums are positively related to recent and future NAV growth. However, there appears to be too much variation in P/NAV, giving rise to potential profits from trading on mean reversion. These results are clearly related to similar findings in the closed-end fund literature. However, REITs have much higher institutional ownership, much higher inside ownership, and pay high levels of dividends. The closed-end fund literature suggests that investment trusts with these characteristics should not deviate very far from fundamental value, and yet we document substantial temporary deviations from $\mathrm{P} / \mathrm{NAV}=1$. Even when we directly control for the extent of institutional ownership by 
sorting the data first by institutional ownership and then by P/NAV, the extent of mispricing, if anything, becomes larger. Thus, individual investor sentiment is unlikely to explain the mean reversion in REIT prices.

Also, the REIT results may be more generalizable because, compared to closed-end funds, REITs more closely resemble the bulk of the equity universe. REITs are typically operating companies rather than passive investors, and the REITs in our sample have much larger average market capitalizations (over \$2 billion vs. just \$400 million for the CRSP universe of closed-end funds as of the end of 2003). While one might ignore closed-end funds as an economically insignificant fraction of publicly held assets, this is harder to do for REITs, and it is not much of a leap to conjecture that there could be similar departures from fundamentals for large-cap stocks. Thus, our results are also related to evidence of differential pricing of two claims to the same assets, such as the divergence between the share prices of Royal Dutch Petroleum and Shell Oil (see, for example, Rashes, 1999; Rosenthal and Young, 1990). However, REIT mispricings appear to be shorter-lived and more consistently exploitable, and thus less subject to the limits of arbitrage.

In fact, the Royal Dutch-Shell example may be related to our work in a second way. Since it is possible to generate estimates of fundamental value for natural resource companies, the same kind of deviations and trading opportunities are likely present in that sector. Analysts often compute the value of oil companies by multiplying proven reserves by the current and future forecast price of oil less extraction costs. In fact, a recent NY Times article (6/12/2004, Page A1) notes that analysts pay much more attention to estimated reserves than actual production in valuing these companies. This observation explains the hubbub over the recent reserves scandal at Shell, in which Shell management overstated oil and gas reserves by 22 percent, resulting in the removal of the company's chairman. Despite the accounting problems, future research might apply this methodology to the natural resources industry or other companies where it is possible to obtain reasonably reliable estimates of the fundamental value of a firm's assets.

Finally, it is worth pointing out that the trading strategy analyzed here is a meanreversion strategy, as opposed to a momentum strategy. This raises the interesting question of why REITs exhibit mean reversion at, say, 3-month horizons, while other stocks and industries exhibit momentum at similar horizons (Jegadeesh and Titman, 1993; Moskowitz and Grinblatt, 
1999). There is some evidence that there is long-term mean reversion for other stocks as well, as momentum appears to reverse at horizons beyond a year, but it is less clear why the mean reversion would operate on such different time scales. One possibility is that fundamental value is easier to observe for REITs, so the mean reversion can take place more quickly. For other operating companies, where fundamental value is more difficult to assess, larger and more persistent deviations from fundamental value can occur. In future work, we intend to pursue further these parallels and contrasts between REITs and other stocks. 


\section{References}

Amihud, Yakov and Haim Mendelson (1986), Asset pricing and the bid-ask spread, Journal of Financial Economics 17(2):223-249.

Barber, Brad, Reuven Lehavy, Maureen McNichols, and Brett Trueman (2001), Can investors profit from the prophets? Security analyst recommendations and stock returns, Journal of Finance 56(2):531-563.

Bonser-Neal, Catherine, Greggory A. Brauer, Robert Neal, and Simon Wheatley (1990), International investment restrictions and closed-end country fund prices, Journal of Finance 45:523-547.

Brickley, James A., Steven Manaster, and James S. Schallheim, 1991, The tax-timing option and the discounts on closed-end investment companies, Journal of Business 64:287-312.

Black, Fisher, Michael C. Jensen, and Myron Scholes (1972), The capital asset pricing model: some empirical tests, in Studies in the Theory of Capital Markets (Michael C. Jensen, ed.), Praeger, Inc.

Campbell, John Y. and Robert J. Shiller (1988), The dividend-price ratio and expectations of future dividends and discount factors, Review of Financial Studies 1(3):195-228.

Capozza, Dennis R. and Paul J. Seguin (2003), Inside ownership, risk sharing and Tobin's q ratio: Evidence from REITs, Real Estate Economics 31(3): 367-404.

Carhart, Mark M. (1997), On persistence in mutual fund performance, Journal of Finance 52(1):57-82.

Chay, Jong-Bom and Charles Trzcinka (1999), Managerial performance and the cross-sectional pricing of closed-end funds, Journal of Financial Economics 52:379-408.

Clayton, Jim and Greg MacKinnon (2003), The Relative Importance of Stock, Bond and Real Estate Factors in Explaining REIT Returns, Journal of Real Estate Finance and Economics 27(1): 39-60.

Cochrane, John H. (2001), Asset Pricing, Princeton University Press.

Coles, Jeffrey, Jose Suay, and Denise Woodbury (2000), Fund advisor compensation in closedend funds, Journal of Finance 55:1385-1414.

D'Avolio, Gene (2002), The market for borrowing stock, Journal of Financial Economics 66(23):271-306.

Dimson, Elroy and Carolina Minio-Kozerski (1999), Closed-end funds: a survey, Financial Markets, Institutions \& Instruments 8(2):1-41. 
Fama, Eugene F. and Kenneth R. French (1993), Common risk factors in the returns on stocks and bonds, Journal of Financial Economics 33(1):3-56.

Geczy, Christopher C., David K. Musto, and Adam V. Reed (2002), Stocks are special too: an analysis of the equity lending market, Journal of Financial Economics 66(2-3):241-269.

Gentry, William M. and Christopher J. Mayer (2003), What Can We Learn about the Sensitivity of Investment to Stock Prices with a Better Measure of Tobin's q?, working paper, Columbia University.

Gentry, William M., Deen Kemsley, and Christopher J. Mayer (2003), Dividend taxes and share prices: evidence from real estate investment trusts, Journal of Finance 58(1):261-282.

Jegadeesh, Narasimhan and Sheridan Titman (1993), Returns to buying winners and selling losers: implications for stock market efficiency, Journal of Finance 48(1):65-91.

Jones, Charles M. and Owen A. Lamont (2002), Short sale constraints and stock returns, Journal of Financial Economics 66(2-3):207-239.

Lee, Charles M.C., Andrei Shleifer, and Richard H. Thaler (1991), Investor sentiment and the closed-end fund puzzle, Journal of Finance 46(1):76-110.

Malkiel, Burton G. (1977), The valuation of closed-end investment-company shares, Journal of Finance 32:847-858.

Moskowitz, Tobias J. and Mark Grinblatt (1999), Do industries explain momentum? Journal of Finance 54(4):1249-1290.

Newey, Whitney K. and Kenneth D. West (1987), A simple, positive semi-definite, heteroskedasticity and autocorrelation consistent covariance matrix, Econometrica 55(3):703708 .

Pontiff, Jeffrey (1995), Closed-end fund premiums and returns; implications for financial market equilibrium, Journal of Financial Economics 37:341-367.

Pontiff, Jeffrey (1996), Costly arbitrage: evidence from closed-end funds, Quarterly Journal of Economics 111:1135-1151.

Rashes, Michael S. (1999), Essays on arbitrage, Ph.D. thesis, Harvard University.

Rosenthal, Leonard and Colin Young (1990), The seemingly anomalous price behavior of Royal Dutch/Shell and Unilever N.V./PLC, Journal of Financial Economics 26(1):123-141.

Shleifer, Andrei and Robert W. Vishny (1997), The limits of arbitrage, Journal of Finance 52(1):35-55. 
Stambaugh, Robert F. (1999), Predictive regressions, Journal of Financial Economics 54(3):375421.

Swaminathan, B. (1996), Time-varying expected small firm returns and closed-end fund discounts, Review of Financial Studies 9:845-887.

Thompson, Rex (1978), The information content of discounts and premiums on closed-end fund shares, Journal of Financial Economics 6:151-186.

Womack, Kent L. (1996), Do brokerage analysts' recommendations have investment value? Journal of Finance 51(1):137-167. 
Table 1

\section{Summary Statistics}

The sample consists of all equity REITs covered by Green Street Advisors from January 1990 to December 2003. REITs are sorted into quartiles based on their ratio of price to NAV. NAV estimates are available quarterly 1990-1993 and monthly beginning in 1994. All summary statistics are calculated based on data from the end of 2001.

Quartile 1 Quartile 2 Quartile 3 Quartile 4

(low P/NAV) (high P/NAV)

Number of REITs in sample

15

15

15

14

Avg. P/NAV

0.95

1.01

1.05

1.16

Avg. market capitalization

1.09

1.25

1.95

3.04

(in billions)

Avg. institutional ownership

$$
54 \%
$$

$54 \%$

$52 \%$

$46 \%$

Avg. inside ownership

$15 \%$

$14 \%$

$11 \%$

$10 \%$

Avg. quoted spread

$0.7 \%$

$0.8 \%$

$0.6 \%$

$0.5 \%$

Avg. daily volume (shares)

140,103

158,395

332,642

423,263

Avg. days to cover

2.95

3.94

5.08

7.02

(short interest / daily volume) 


\begin{tabular}{|c|c|c|c|c|c|c|}
\hline \multicolumn{7}{|c|}{$\begin{array}{l}\text { Table 2a: REIT Stock Market Return, by P/NAV Quartile, 01/1990 to 12/2003 } \\
\text { Dependent variable: value-weighted portfolio return }\end{array}$} \\
\hline & \multirow[t]{2}{*}{ One Day } & \multirow[t]{2}{*}{ One Week } & \multicolumn{2}{|c|}{ One Month } & \multicolumn{2}{|c|}{ Three Months } \\
\hline & & & No FF & Include FF & No FF & Include FF \\
\hline Portfolio 1 & \multicolumn{6}{|c|}{ Lowest P/NAV Quartile } \\
\hline$\alpha$ & $\begin{array}{l}0.0013 * \\
(.00065)\end{array}$ & $\begin{array}{l}0.0028 \\
(.0017)\end{array}$ & $\begin{array}{r}0.0084 * * \\
(0.0031)\end{array}$ & $\begin{array}{r}0.0066 * * \\
(.0027)\end{array}$ & $\begin{array}{r}0.0087 \\
(0.0095)\end{array}$ & $\begin{array}{r}0.0039 \\
(0.0066)\end{array}$ \\
\hline$\beta$ & $\begin{array}{r}0.45 * * \\
(.063)\end{array}$ & $\begin{array}{l}0.47 * * \\
(0.078)\end{array}$ & $\begin{array}{r}0.46 * * \\
(0.078)\end{array}$ & $\begin{array}{r}0.47^{* *} \\
(0.068)\end{array}$ & $\begin{array}{r}0.55 * * \\
(0.087)\end{array}$ & $\begin{array}{r}0.52 * * \\
(0.061)\end{array}$ \\
\hline SMB & & & & $\begin{array}{l}0.45 * * \\
(0.075)\end{array}$ & & $\begin{array}{l}0.47 * * \\
(0.069)\end{array}$ \\
\hline HML & & & & $\begin{array}{l}0.33 * * \\
(0.062) \\
\end{array}$ & & $\begin{array}{l}0.45^{* *} \\
(0.049) \\
\end{array}$ \\
\hline \multicolumn{7}{|l|}{ Portfolio 2} \\
\hline$\alpha$ & $\begin{array}{r}0.00077 \\
(0.00051)\end{array}$ & $\begin{array}{r}0.000023 \\
(0.0016)\end{array}$ & $\begin{array}{r}0.0069 * * \\
(0.0030)\end{array}$ & $\begin{array}{l}0.0054 * \\
(0.0028)\end{array}$ & $\begin{array}{r}0.013 \\
(0.0080)\end{array}$ & $\begin{array}{r}0.0092 \\
(0.0063)\end{array}$ \\
\hline$\beta$ & $\begin{array}{l}0.41 * * \\
(0.050)\end{array}$ & $\begin{array}{l}0.53 * * \\
(0.074)\end{array}$ & $\begin{array}{l}0.31 * * \\
(0.074)\end{array}$ & $\begin{array}{l}0.32 * * \\
(0.068)\end{array}$ & $\begin{array}{l}0.42 * * \\
(0.085)\end{array}$ & $\begin{array}{l}0.40 * * \\
(0.069)\end{array}$ \\
\hline SMB & & & & $\begin{array}{l}0.34 * * \\
(0.076)\end{array}$ & & $\begin{array}{l}0.39 * * \\
(0.081)\end{array}$ \\
\hline HML & & & & $\begin{array}{l}0.27 * * \\
(0.062) \\
\end{array}$ & & $\begin{array}{l}0.31 * * \\
(0.064) \\
\end{array}$ \\
\hline \multicolumn{7}{|l|}{ Portfolio 3} \\
\hline$\alpha$ & $\begin{array}{r}0.00083 \\
(0.00054)\end{array}$ & $\begin{array}{r}-0.00025 \\
(0.0017)\end{array}$ & $\begin{array}{r}0.0032 \\
(0.0034)\end{array}$ & $\begin{array}{r}0.0016 \\
(0.0032)\end{array}$ & $\begin{array}{r}0.0046 \\
(0.0084)\end{array}$ & $\begin{array}{r}0.0010 \\
(0.0068)\end{array}$ \\
\hline$\beta$ & $\begin{array}{l}0.36 * * \\
(0.053)\end{array}$ & $\begin{array}{l}0.52 * * \\
(0.079)\end{array}$ & $\begin{array}{l}0.36 * * \\
(0.086)\end{array}$ & $\begin{array}{l}0.37^{* *} \\
(0.079)\end{array}$ & $\begin{array}{l}0.46 * * \\
(0.085)\end{array}$ & $\begin{array}{l}0.44 * * \\
(0.071)\end{array}$ \\
\hline SMB & & & & $\begin{array}{l}0.38 * * \\
(0.088)\end{array}$ & & $\begin{array}{l}0.33 * * \\
(0.094)\end{array}$ \\
\hline HML & & & & $\begin{array}{l}0.33 * * \\
(0.072) \\
\end{array}$ & & $\begin{array}{l}0.33 * * \\
(0.071) \\
\end{array}$ \\
\hline Portfolio 4 & Highest P/NA & Quartile & & & & \\
\hline$\alpha$ & $\begin{array}{r}0.00027 \\
(0.00058)\end{array}$ & $\begin{array}{r}-0.0017 \\
(.0016)\end{array}$ & $\begin{array}{r}-0.0017 \\
(0.0031)\end{array}$ & $\begin{array}{l}-0.0028 \\
\quad(0.0029)\end{array}$ & $\begin{array}{r}-0.0012 \\
(0.0082)\end{array}$ & $\begin{array}{r}-0.0037 \\
(0.0076)\end{array}$ \\
\hline$\beta$ & $\begin{array}{l}0.33 * * \\
(0.056)\end{array}$ & $\begin{array}{l}0.40 * * \\
(0.070)\end{array}$ & $\begin{array}{l}0.28 * * \\
(0.076)\end{array}$ & $\begin{array}{l}0.29 * * \\
(0.072)\end{array}$ & $\begin{array}{c}0.40 * * \\
(0.084)\end{array}$ & $\begin{array}{c}0.38 * * \\
(0.080)\end{array}$ \\
\hline SMB & & & & $\begin{array}{l}0.23 * * \\
(0.081)\end{array}$ & & $\begin{array}{l}0.22 * * \\
(0.097)\end{array}$ \\
\hline HML & & & & $\begin{array}{l}0.24 * * \\
(0.066)\end{array}$ & & $\begin{array}{l}0.22 * * \\
(0.079)\end{array}$ \\
\hline
\end{tabular}

$\mathrm{N}=136$ for one-day, one-month, and one-month regressions; $\mathrm{N}=134$ for three-month regressions.

Each portfolio model is estimated separately using weighted-least squares (weight $=$ the number of REITs in the portfolio that month) on value-weighted stock market returns and Fama-French factors. Standard errors are in parentheses. For the overlapping three-month intervals, standard errors are corrected using the Newey-West procedure. $*$ denotes statistical significance at the $90 \%$ confidence level and $* *$ at the $95 \%$ confidence level. The data are quarterly from 1990 to 1993 and monthly from 1994 to 2003. 
Table 2b: Differential Returns on Low Minus High Value REITs, 01/1990 to 12/2003

Dependent variable: value-weighted portfolio return

\begin{tabular}{|c|c|c|c|c|c|c|}
\hline & \multirow[t]{2}{*}{ One Day } & \multirow[t]{2}{*}{ One Week } & \multicolumn{2}{|c|}{ One Month } & \multicolumn{2}{|c|}{ Three Months } \\
\hline & & & No FF & Include FF & No FF & Include FF \\
\hline \multicolumn{7}{|c|}{ Portfolio 1 - Portfolio 4} \\
\hline$\alpha$ & $\begin{array}{r}0.00097 \\
(0.00065)\end{array}$ & $\begin{array}{r}0.0045 * * \\
(0.0012)\end{array}$ & $\begin{array}{l}0.010 * * \\
(0.0022)\end{array}$ & $\begin{array}{r}0.0094 * * \\
(0.0021)\end{array}$ & $\begin{array}{r}0.010 \\
(0.0066)\end{array}$ & $\begin{array}{r}0.0077 \\
(0.0056)\end{array}$ \\
\hline$\beta$ & $\begin{array}{r}0.12 * \\
(0.063)\end{array}$ & $\begin{array}{r}0.071 \\
(0.052)\end{array}$ & $\begin{array}{l}0.18 * * \\
(0.056)\end{array}$ & $\begin{array}{l}0.18 * * \\
(0.053)\end{array}$ & $\begin{array}{l}0.16^{* *} \\
(0.069)\end{array}$ & $\begin{array}{l}0.14 * * \\
(0.060)\end{array}$ \\
\hline SMB & & & & $\begin{array}{l}0.22 * * \\
(0.059)\end{array}$ & & $\begin{array}{l}0.25 * * \\
(0.088)\end{array}$ \\
\hline HML & & & & $\begin{array}{l}0.086 * \\
(0.049)\end{array}$ & & $\begin{array}{l}0.23 * * \\
(0.062)\end{array}$ \\
\hline
\end{tabular}

$\mathrm{N}=136$ for one-day, one-month, and one-month regressions; $\mathrm{N}=134$ for three-month regressions.

Each portfolio model is estimated separately using weighted-least squares (weight $=$ the number of REITs in the portfolio that month) on value-weighted stock market returns and Fama-French factors. Standard errors are in parentheses. For the overlapping three-month intervals, the standard errors are corrected using the Newey-West procedure. $*$ denotes statistical significance at the $90 \%$ confidence level and $* *$ at the $95 \%$ confidence level. The data are quarterly from 1990 to 1993 and monthly from 1994 to 2003. 


\begin{tabular}{|c|c|c|c|c|c|c|}
\hline \multicolumn{7}{|c|}{$\begin{array}{c}\text { Table 3a: REIT Stock Market Return Regressions Conditional on Absolute Level of P/NAV } \\
\text { Dependent variable: value-weighted portfolio return }\end{array}$} \\
\hline & \multirow[t]{2}{*}{ One Day } & \multirow[t]{2}{*}{ One Week } & \multicolumn{2}{|c|}{ One Month } & \multicolumn{2}{|c|}{ Three Month } \\
\hline & & & No FF & Include FF & No FF & Include FF \\
\hline Portfolio 1 & $(\mathrm{~N}=116)$ & $\mathrm{P} / \mathrm{NAV}<90 \%$ & & & & \\
\hline$\alpha$ & $\begin{array}{r}0.0012 * \\
(0.00072)\end{array}$ & $\begin{array}{r}0.0033 \\
(0.0020)\end{array}$ & $\begin{array}{l}0.013 * * \\
(0.0038)\end{array}$ & $\begin{array}{l}0.011 * * \\
(0.0034)\end{array}$ & $\begin{array}{l}0.025 * \\
(0.013)\end{array}$ & $\begin{array}{r}0.012 \\
(0.013)\end{array}$ \\
\hline$\beta$ & $\begin{array}{r}0.34 * * \\
(0.064)\end{array}$ & $\begin{array}{r}0.39 * * \\
(0.099)\end{array}$ & $\begin{array}{r}0.42 * * \\
(0.96)\end{array}$ & $\begin{array}{r}0.51 * * \\
(0.086)\end{array}$ & $\begin{array}{r}0.55 * * \\
(0.14)\end{array}$ & $\begin{array}{l}0.66 * * \\
(0.084)\end{array}$ \\
\hline SMB & & & & $\begin{array}{l}0.43 * * \\
(0.086)\end{array}$ & & $\begin{array}{r}0.50 * * \\
(0.12)\end{array}$ \\
\hline HML & & & & $\begin{array}{l}0.36 * * \\
(0.058)\end{array}$ & & $\begin{array}{l}0.39 * * \\
(0.071)\end{array}$ \\
\hline Portfolio 2 & $(\mathrm{~N}=134)$ & $90 \%<\mathrm{P} / \mathrm{NAV}<$ & & & & \\
\hline$\alpha$ & $\begin{array}{r}0.0011 * \\
(0.00058)\end{array}$ & $\begin{array}{r}0.00028 \\
(0.0019)\end{array}$ & $\begin{array}{r}0.0049 \\
(0.0031)\end{array}$ & $\begin{array}{r}0.0031 \\
(0.0028)\end{array}$ & $\begin{array}{r}0.0071 \\
(0.0089)\end{array}$ & $\begin{array}{r}0.0026 \\
(0.0067)\end{array}$ \\
\hline$\beta$ & $\begin{array}{l}0.47 * * \\
(0.052)\end{array}$ & $\begin{array}{l}0.52 * * \\
(0.077)\end{array}$ & $\begin{array}{l}0.36 * * \\
(0.073)\end{array}$ & $\begin{array}{l}0.34 * * \\
(0.067)\end{array}$ & $\begin{array}{l}0.44 * * \\
(0.087)\end{array}$ & $\begin{array}{l}0.44 * * \\
(0.069)\end{array}$ \\
\hline SMB & & & & $\begin{array}{l}0.34 * * \\
(0.079)\end{array}$ & & $\begin{array}{l}0.28 * * \\
(0.083)\end{array}$ \\
\hline HML & & & & $\begin{array}{l}0.28 * * \\
(0.062) \\
\end{array}$ & & $\begin{array}{l}0.31 * * \\
(0.084)\end{array}$ \\
\hline Portfolio 3 & $(\mathrm{~N}=133)$ & $100 \%<\mathrm{P} / \mathrm{NAV}<$ & $0 \%$ & & & \\
\hline$\alpha$ & $\begin{array}{r}0.0013 * * \\
(0.00051)\end{array}$ & $\begin{array}{r}-0.00080 \\
(0.0016)\end{array}$ & $\begin{array}{r}0.0014 \\
(0.0032)\end{array}$ & $\begin{array}{r}0.000028 \\
(0.0030)\end{array}$ & $\begin{array}{r}-0.0018 \\
(0.0087)\end{array}$ & $\begin{array}{l}-0.0037 \\
(0.0069)\end{array}$ \\
\hline$\beta$ & $\begin{array}{l}0.34 * * \\
(0.050)\end{array}$ & $\begin{array}{l}0.57 * * \\
(0.071)\end{array}$ & $\begin{array}{l}0.33 * * \\
(0.079)\end{array}$ & $\begin{array}{l}0.30 * * \\
(0.075)\end{array}$ & $\begin{array}{l}0.48 * * \\
(0.085)\end{array}$ & $\begin{array}{l}0.43 * * \\
(0.080)\end{array}$ \\
\hline SMB & & & & $\begin{array}{l}0.34 * * \\
(0.089)\end{array}$ & & $\begin{array}{r}0.26 * * \\
(0.11)\end{array}$ \\
\hline HML & & & & $\begin{array}{l}0.26 * * \\
(0.088)\end{array}$ & & $\begin{array}{r}0.28 * * \\
(0.10) \\
\end{array}$ \\
\hline Portfolio 4 & $(\mathrm{~N}=128)$ & $\mathrm{P} / \mathrm{NAV}>110 \%$ & & & & \\
\hline$\alpha$ & $\begin{array}{r}-0.000073 \\
(0.00051)\end{array}$ & $\begin{array}{r}-0.00095 \\
(0.0014)\end{array}$ & $\begin{array}{r}-0.00045 \\
(0.0030)\end{array}$ & $\begin{array}{r}-0.0013 \\
(0.0028)\end{array}$ & $\begin{array}{r}-0.0041 \\
(0.0095)\end{array}$ & $\begin{array}{l}-0.0046 \\
(0.0073)\end{array}$ \\
\hline$\beta$ & $\begin{array}{l}0.40 * * \\
(0.060)\end{array}$ & $\begin{array}{l}0.43 * * \\
(0.064)\end{array}$ & $\begin{array}{l}0.33 * * \\
(0.079)\end{array}$ & $\begin{array}{l}0.33 * * \\
(0.075)\end{array}$ & $\begin{array}{r}0.44 * * \\
(0.10)\end{array}$ & $\begin{array}{r}0.39 * * \\
(0.10)\end{array}$ \\
\hline SMB & & & & $\begin{array}{l}0.35 * * \\
(0.083)\end{array}$ & & $\begin{array}{r}0.32 * * \\
(0.12)\end{array}$ \\
\hline HML & & & & $\begin{array}{r}0.19 * \\
(0.098)\end{array}$ & & $\begin{array}{r}0.40 * * \\
(0.11)\end{array}$ \\
\hline
\end{tabular}

Each portfolio model is estimated separately using weighted-least squares (weight $=$ the number of REITs in the portfolio that month) on value-weighted stock market returns and Fama-French factors. Standard errors are in parentheses. For the overlapping three-month intervals, the standard errors are corrected using the Newey-West procedure. * denotes statistical significance at the $90 \%$ confidence level and $* *$ at the $95 \%$ confidence level. The data are quarterly from 1990 to 1993 and monthly from 1994 to 2003. 


\begin{tabular}{|c|c|c|c|c|c|c|}
\hline \multicolumn{7}{|c|}{$\begin{array}{c}\text { Table 3b: REIT Stock Market Return Regressions Conditional on Absolute Level of P/NAV } \\
\text { 01/1990 to } 12 / 2003 \text {, } \\
\text { Dependent variable: value-weighted portfolio return }\end{array}$} \\
\hline & \multirow[t]{2}{*}{ One Day } & \multirow[t]{2}{*}{ One Week } & \multicolumn{2}{|c|}{ One Month } & \multicolumn{2}{|c|}{ Three Month } \\
\hline & & & No FF & Include FF & No FF & Include FF \\
\hline \multicolumn{7}{|c|}{ Portfolio 1} \\
\hline$\alpha$ & $\begin{array}{l}0.0017 * * \\
(0.00079)\end{array}$ & $\begin{array}{r}0.0024 \\
(0.0021)\end{array}$ & $\begin{array}{c}0.011 * * \\
(0.0040)\end{array}$ & $\begin{array}{r}0.0079 * * \\
(0.0036)\end{array}$ & $\begin{array}{r}0.016 \\
(0.012)\end{array}$ & $\begin{array}{r}-0.0022 \\
(0.0080)\end{array}$ \\
\hline$\beta$ & $\begin{array}{r}0.39 * * \\
(0.077)\end{array}$ & $\begin{array}{r}0.43 * * \\
(0.093)\end{array}$ & $\begin{array}{r}0.60 * * \\
(0.10)\end{array}$ & $\begin{array}{r}0.54 * \\
(0.093)\end{array}$ & $\begin{array}{r}0.62 * * \\
(0.16)\end{array}$ & $\begin{array}{r}0.70 * * \\
(0.10)\end{array}$ \\
\hline SMB & & & & $\begin{array}{r}0.59 * * \\
(0.11)\end{array}$ & & $\begin{array}{r}0.61 \text { ** } \\
(0.14)\end{array}$ \\
\hline HML & & & & $\begin{array}{l}0.19 * * \\
(0.072)\end{array}$ & & $\begin{array}{l}0.46 \text { ** } \\
(0.091)\end{array}$ \\
\hline \multicolumn{7}{|c|}{ Portfolio 4} \\
\hline$\alpha$ & $\begin{array}{c}-0.000038 \\
(0.00057)\end{array}$ & $\begin{array}{r}-0.0021 \\
(0.0015)\end{array}$ & $\begin{array}{r}-0.0037 \\
(0.0031)\end{array}$ & $\begin{array}{r}-0.0044 \\
(0.0028)\end{array}$ & $\begin{array}{r}0.0022 \\
(0.0095)\end{array}$ & $\begin{array}{r}0.0013 \\
(0.0084)\end{array}$ \\
\hline$\beta$ & $\begin{array}{l}0.44 * * \\
(0.060)\end{array}$ & $\begin{array}{r}0.52 * \\
(0.068)\end{array}$ & $\begin{array}{l}0.31 * * \\
(0.086)\end{array}$ & $\begin{array}{c}0.19 * * \\
(0.083)\end{array}$ & $\begin{array}{c}0.39 * * \\
(0.082)\end{array}$ & $\begin{array}{l}0.30 \text { ** } \\
(0.082)\end{array}$ \\
\hline SMB & & & & $\begin{array}{r}0.40 * * \\
(0.10)\end{array}$ & & $\begin{array}{r}0.24 \\
(0.15)\end{array}$ \\
\hline HML & & & & $\begin{array}{r}0.28 * * \\
(0.10)\end{array}$ & & $\begin{array}{r}0.44 * * \\
(0.14)\end{array}$ \\
\hline \multicolumn{7}{|c|}{ Portfolio 1 minus Portfolio 4} \\
\hline$\alpha$ & $\begin{array}{c}0.0019 * * \\
(0.00086)\end{array}$ & $\begin{array}{l}0.0074 * \\
(0.0016)\end{array}$ & $\begin{array}{l}0.018 * * \\
(0.0034)\end{array}$ & $\begin{array}{c}0.017 * * \\
(0.0034)\end{array}$ & $\begin{array}{r}0.021 * * \\
(0.010)\end{array}$ & $\begin{array}{l}0.017 \text { * } \\
(0.010)\end{array}$ \\
\hline$\beta$ & $\begin{array}{r}0.044 \\
(0.088)\end{array}$ & $\begin{array}{r}0.14 * \\
(0.075)\end{array}$ & $\begin{array}{l}0.26 * * \\
(0.091)\end{array}$ & $\begin{array}{l}0.22 * * \\
(0.092)\end{array}$ & $\begin{array}{r}0.28 * * \\
(0.12)\end{array}$ & $\begin{array}{r}0.21 * * \\
(0.10)\end{array}$ \\
\hline SMB & & & & $\begin{array}{r}0.24 * * \\
(0.11)\end{array}$ & & $\begin{array}{r}0.44 * * \\
(0.17)\end{array}$ \\
\hline HML & & & & $\begin{array}{r}0.052 \\
(0.083) \\
\end{array}$ & & $\begin{array}{l}0.18 * \\
(0.10)\end{array}$ \\
\hline
\end{tabular}

The regressions only include month-years with observations for both Portfolio 1 and Portfolio 4. $\mathrm{N}=108$ for one-day, one-month, and one-month regressions; $\mathrm{N}=106$ for three-month regressions.

Each portfolio model is estimated separately using weighted-least squares (weight $=$ the number of REITs in the portfolio that month) on value-weighted stock market returns and Fama-French factors. Standard errors are in parentheses. For the overlapping three-month intervals, the standard errors are corrected using the Newey-West procedure. $*$ denotes statistical significance at the $90 \%$ confidence level and $* *$ at the $95 \%$ confidence level. The data are quarterly from 1990 to 1993 and monthly from 1994 to 2003. 
Table 4a: REIT Return, by P/NAV Quartile, 01/1990 to 10/2003

Dependent Variable: One month value-weighted portfolio return

\begin{tabular}{|c|c|c|c|c|}
\hline & \multicolumn{2}{|c|}{$\begin{array}{l}\text { Estimated without REITs in } \\
\text { the Highest Quartile of Bid- } \\
\text { Ask Every Month }\end{array}$} & \multicolumn{2}{|c|}{$\begin{array}{l}\text { Double-Sorted Portfolios, } \\
\text { First by Bid-Ask, then by } \\
\text { Price/NAV }\end{array}$} \\
\hline & No FF & Include FF & No FF & Include FF \\
\hline Portfolio 1 & \multicolumn{4}{|c|}{ Lowest P/NAV Quartile } \\
\hline$\alpha$ & $\begin{array}{r}0.0099 * * \\
(0.0031)\end{array}$ & $\begin{array}{r}0.0083 * * \\
(0.0028)\end{array}$ & $\begin{array}{r}0.0092 * * \\
(0.0031)\end{array}$ & $\begin{array}{r}0.0073 * * \\
(0.0028)\end{array}$ \\
\hline$\beta$ & $\begin{array}{l}0.41 * * \\
(0.078)\end{array}$ & $\begin{array}{l}0.42 * * \\
(0.070)\end{array}$ & $\begin{array}{l}0.42 * * \\
(0.077)\end{array}$ & $\begin{array}{l}0.43 * * \\
(0.070)\end{array}$ \\
\hline SMB & & $\begin{array}{l}0.41 * * \\
(0.078)\end{array}$ & & $\begin{array}{l}0.40 * * \\
(0.077)\end{array}$ \\
\hline HML & & $\begin{array}{l}0.28 * * \\
(0.064)\end{array}$ & & $\begin{array}{l}0.29 * * \\
(0.063)\end{array}$ \\
\hline \multicolumn{5}{|l|}{ Portfolio 2} \\
\hline$\alpha$ & $\begin{array}{r}0.0069 * * \\
(0.0032)\end{array}$ & $\begin{array}{l}0.0055 * \\
(0.0030)\end{array}$ & $\begin{array}{r}0.0066 * * \\
(0.0033)\end{array}$ & $\begin{array}{r}0.0049 \\
(0.0030)\end{array}$ \\
\hline$\beta$ & $\begin{array}{l}0.33 * * \\
(0.079)\end{array}$ & $\begin{array}{l}0.34 * * \\
(0.073)\end{array}$ & $\begin{array}{l}0.34 * * \\
(0.082)\end{array}$ & $\begin{array}{l}0.35 \text { ** } \\
(0.074)\end{array}$ \\
\hline SMB & & $\begin{array}{l}0.34 * * \\
(0.082)\end{array}$ & & $\begin{array}{l}0.40 * * \\
(0.083)\end{array}$ \\
\hline HML & & $\begin{array}{l}0.25 * * \\
(0.067)\end{array}$ & & $\begin{array}{l}0.32 * * \\
(0.068)\end{array}$ \\
\hline \multicolumn{5}{|l|}{ Portfolio 3} \\
\hline$\alpha$ & $\begin{array}{r}0.0029 \\
(0.0035)\end{array}$ & $\begin{array}{r}0.0014 \\
(0.0033)\end{array}$ & $\begin{array}{r}0.0013 \\
(0.0031)\end{array}$ & $\begin{array}{r}-0.000026 \\
(0.0029)\end{array}$ \\
\hline$\beta$ & $\begin{array}{l}0.34 * * \\
(0.087)\end{array}$ & $\begin{array}{l}0.35 * * \\
(0.082)\end{array}$ & $\begin{array}{l}0.33 * * \\
(0.078)\end{array}$ & $\begin{array}{l}0.34 * * \\
(0.072)\end{array}$ \\
\hline SMB & & $\begin{array}{l}0.36 * * \\
(0.091)\end{array}$ & & $\begin{array}{l}0.31 \text { ** } \\
(0.081)\end{array}$ \\
\hline HML & & $\begin{array}{l}0.31 * * \\
(0.074)\end{array}$ & & $\begin{array}{l}0.27 * * \\
(0.066)\end{array}$ \\
\hline Portfolio 4 & \multicolumn{4}{|c|}{ Highest P/NAV Quartile } \\
\hline$\alpha$ & $\begin{array}{r}-0.00084 \\
(0.0031)\end{array}$ & $\begin{array}{r}-0.0019 \\
(0.0030)\end{array}$ & $\begin{array}{r}-0.0030 \\
(0.0031)\end{array}$ & $\begin{array}{r}-0.0041 \\
(0.0030)\end{array}$ \\
\hline$\beta$ & $\begin{array}{l}0.27 * * \\
(0.077)\end{array}$ & $\begin{array}{l}0.28 * * \\
(0.073)\end{array}$ & $\begin{array}{l}0.28 * * \\
(0.078)\end{array}$ & $\begin{array}{l}0.30 * * \\
(0.074)\end{array}$ \\
\hline SMB & & $\begin{array}{l}0.22 * * \\
(0.082)\end{array}$ & & $\begin{array}{l}0.24 * * \\
(0.082)\end{array}$ \\
\hline HML & & $\begin{array}{l}0.26 * * \\
(0.067)\end{array}$ & & $\begin{array}{l}0.27 * * \\
(0.066)\end{array}$ \\
\hline
\end{tabular}

$\mathrm{N}=136$. Each portfolio model is estimated separately using weighted-least squares (weight $=$ the number of REITs in the portfolio that month) on value-weighted stock market returns and Fama-French factors. Standard errors are in parentheses. For the overlapping three-month intervals, the standard errors are corrected using the Newey-West procedure. ${ }^{*}$ denotes statistical significance at the $90 \%$ confidence level and ${ }^{* *}$ at the $95 \%$ confidence level. The data are quarterly from 1990 to 1993 and monthly from 1994 to 2003. 


\begin{tabular}{|c|c|c|c|c|}
\hline \multicolumn{5}{|c|}{ Table 4b: Differential Returns on Low Minus High Value REITs } \\
\hline & \multicolumn{2}{|c|}{$\begin{array}{l}\text { Estimated without REITs in } \\
\text { the Highest Quartile of Bid- } \\
\text { Ask Every Month }\end{array}$} & \multicolumn{2}{|c|}{$\begin{array}{l}\text { Double-Sorted Portfolios, } \\
\text { First by Bid-Ask, then by } \\
\text { Price/NAV }\end{array}$} \\
\hline & \multicolumn{2}{|c|}{ One Month } & \multicolumn{2}{|c|}{ One Month } \\
\hline & No FF & Include FF & No FF & Include FF \\
\hline \multicolumn{5}{|c|}{ Portfolio 1 - Portfolio 4} \\
\hline$\alpha$ & $\begin{array}{l}0.011 * * \\
(0.0021)\end{array}$ & $\begin{array}{l}0.010 * * \\
(0.0021)\end{array}$ & $\begin{array}{l}0.012 * * \\
(0.0019)\end{array}$ & $\begin{array}{l}0.012 * * \\
(0.0019)\end{array}$ \\
\hline$\beta$ & $\begin{array}{l}0.14 * * \\
(0.053)\end{array}$ & $\begin{array}{l}0.14 * * \\
(0.052)\end{array}$ & $\begin{array}{l}0.13 * * \\
(0.048)\end{array}$ & $\begin{array}{l}0.13 * * \\
(0.046)\end{array}$ \\
\hline SMB & & $\begin{array}{l}0.18 * * \\
(0.058)\end{array}$ & & $\begin{array}{l}0.15 * * \\
(0.052)\end{array}$ \\
\hline HML & & $\begin{array}{r}0.025 \\
(0.047)\end{array}$ & & $\begin{array}{l}0.0099 \\
(0.042)\end{array}$ \\
\hline
\end{tabular}

$\mathrm{N}=136$. Each portfolio model is estimated separately using weighted-least squares (weight = the number of REITs in the portfolio that month) on value-weighted stock market returns and Fama-French factors. Standard errors are in parentheses. For the overlapping three-month intervals, the standard errors are corrected using the Newey-West procedure. $*$ denotes statistical significance at the $90 \%$ confidence level and $* *$ at the $95 \%$ confidence level. The data are quarterly from 1990 to 1993 and monthly from 1994 to 2003. 


\begin{tabular}{|c|c|c|c|c|}
\hline & \multicolumn{4}{|c|}{$\begin{array}{l}\text { Table 5a: REIT NAV Returns by P/NAV Quartile } \\
\text { Dependent variable: value-weighted NAV return }\end{array}$} \\
\hline & \multicolumn{2}{|c|}{ One Month } & \multicolumn{2}{|c|}{ Three Month } \\
\hline & No FF & Include FF & No FF & Include FF \\
\hline Portfolio 1 & \multicolumn{4}{|c|}{ Lowest P/NAV Quartile } \\
\hline$\alpha$ & $\begin{array}{r}-0.0038 * * \\
(.0017)\end{array}$ & $\begin{array}{r}-0.0040 * * \\
(0.0017)\end{array}$ & $\begin{array}{r}-0.0084 * * \\
(0.0040)\end{array}$ & $\begin{array}{r}-0.0093 * * \\
(0.0038)\end{array}$ \\
\hline$\beta$ & $\begin{array}{l}0.13 * * \\
(0.042)\end{array}$ & $\begin{array}{l}0.13 * * \\
(0.042)\end{array}$ & $\begin{array}{l}0.15 * * \\
(0.060)\end{array}$ & $\begin{array}{l}0.15 * * \\
(0.053)\end{array}$ \\
\hline SMB & & $\begin{array}{l}0.049 \\
(.047)\end{array}$ & & $\begin{array}{r}0.068 \\
(0.061)\end{array}$ \\
\hline HML & & $\begin{array}{l}0.055 \\
(.038) \\
\end{array}$ & & $\begin{array}{r}0.094 * * \\
(0.038) \\
\end{array}$ \\
\hline \multicolumn{5}{|l|}{ Portfolio 2} \\
\hline$\alpha$ & $\begin{array}{r}0.0035 * * \\
(0.0013)\end{array}$ & $\begin{array}{r}0.0034 * * \\
(0.0013)\end{array}$ & $\begin{array}{l}0.011 * * \\
(0.0039)\end{array}$ & $\begin{array}{r}0.011 * * \\
(0.004)\end{array}$ \\
\hline$\beta$ & $\begin{array}{l}0.10 * * \\
(0.032)\end{array}$ & $\begin{array}{l}0.10 * * \\
(0.032)\end{array}$ & $\begin{array}{l}0.11 * * \\
(0.035)\end{array}$ & $\begin{array}{r}0.097 * * \\
(0.035)\end{array}$ \\
\hline SMB & & $\begin{array}{r}0.045 \\
(0.035)\end{array}$ & & $\begin{array}{r}0.076 \\
(0.051)\end{array}$ \\
\hline HML & & $\begin{array}{r}0.0050 \\
(0.029)\end{array}$ & & $\begin{array}{r}0.0086 \\
(0.025)\end{array}$ \\
\hline \multicolumn{5}{|l|}{ Portfolio 3} \\
\hline$\alpha$ & $\begin{array}{r}0.0062 * * \\
(0.0013)\end{array}$ & $\begin{array}{r}0.0060 * * \\
(0.0013)\end{array}$ & $\begin{array}{l}0.016 * * \\
(0.0038)\end{array}$ & $\begin{array}{l}0.016^{* *} \\
(0.0036)\end{array}$ \\
\hline$\beta$ & $\begin{array}{r}0.098 * * \\
(0.032)\end{array}$ & $\begin{array}{r}0.098 * * \\
(0.032)\end{array}$ & $\begin{array}{l}0.15 * * \\
(0.041)\end{array}$ & $\begin{array}{l}0.14 * * \\
(0.041)\end{array}$ \\
\hline SMB & & $\begin{array}{r}0.058 \\
(0.035)\end{array}$ & & $\begin{array}{r}0.057 \\
(0.050)\end{array}$ \\
\hline HML & & $\begin{array}{r}0.0098 \\
(0.029) \\
\end{array}$ & & $\begin{array}{r}0.026 \\
(0.025)\end{array}$ \\
\hline Portfolio 4 & \multicolumn{4}{|c|}{ Highest P/NAV Quartile } \\
\hline$\alpha$ & $\begin{array}{r}0.010 * * \\
(0.001)\end{array}$ & $\begin{array}{r}0.010 * * \\
(0.001)\end{array}$ & $\begin{array}{l}0.024 * * \\
(0.0040)\end{array}$ & $\begin{array}{l}0.025 * * \\
(0.0039)\end{array}$ \\
\hline$\beta$ & $\begin{array}{l}0.056 * \\
(0.031)\end{array}$ & $\begin{array}{l}0.054 * \\
(0.032)\end{array}$ & $\begin{array}{l}0.15 * * \\
(0.040)\end{array}$ & $\begin{array}{l}0.15 * * \\
(0.042)\end{array}$ \\
\hline SMB & & $\begin{array}{r}0.024 \\
(0.035)\end{array}$ & & $\begin{array}{r}-0.015 \\
(0.052)\end{array}$ \\
\hline HML & & $\begin{array}{l}-0.020 \\
(0.029)\end{array}$ & & $\begin{array}{l}-0.012 \\
(0.030)\end{array}$ \\
\hline
\end{tabular}

$\mathrm{N}=136$ for one-day, one-month, and one-month regressions; $\mathrm{N}=134$ for three-month regressions.

Each portfolio model is estimated separately using weighted-least squares (weight $=$ the number of REITs in the portfolio that month) on value-weighted stock market returns and Fama-French factors. Standard errors are in parentheses. For the overlapping three-month intervals, the standard errors are corrected using the Newey-West procedure. $*$ denotes statistical significance at the $90 \%$ confidence level and $* *$ at the $95 \%$ confidence level. The data are quarterly from 1990 to 1993 and monthly from 1994 to 2003. 


\begin{tabular}{|c|c|c|c|c|}
\hline \multicolumn{5}{|c|}{$\begin{array}{c}\text { Table 5b: Differential NAV Returns on Low Minus High Value REITs, } \\
\text { 01/1990 to } 12 / 2003 \\
\text { Dependent variable: value-weighted NAV return }\end{array}$} \\
\hline & \multicolumn{2}{|c|}{ One Month } & \multicolumn{2}{|c|}{ Three Month } \\
\hline & No FF & Include FF & No FF & Include FF \\
\hline \multicolumn{5}{|c|}{ Portfolio 1 - Portfolio 4} \\
\hline$\alpha$ & $\begin{array}{r}-0.014 * * \\
(0.0014)\end{array}$ & $\begin{array}{r}-0.014 * * \\
(0.001)\end{array}$ & $\begin{array}{r}-0.032 * * \\
(0.0032)\end{array}$ & $\begin{array}{r}-0.034 * * \\
(0.003)\end{array}$ \\
\hline$\beta$ & $\begin{array}{r}0.072 * * \\
(0.035)\end{array}$ & $\begin{array}{r}0.075 * * \\
(0.035)\end{array}$ & $\begin{array}{r}0.0047 \\
(0.052)\end{array}$ & $\begin{array}{r}-0.00097 \\
(0.039)\end{array}$ \\
\hline SMB & & $\begin{array}{r}0.023 \\
(0.039)\end{array}$ & & $\begin{array}{r}0.083 * * \\
(0.041)\end{array}$ \\
\hline HML & & $\begin{array}{r}0.074 * * \\
(0.031)\end{array}$ & & $\begin{array}{r}0.105 * * \\
(0.033)\end{array}$ \\
\hline
\end{tabular}

$\mathrm{N}=136$ for one-month regressions; $\mathrm{N}=134$ for three-month regressions.

Each portfolio model is estimated separately using weighted-least squares (weight $=$ the number of REITs in the portfolio that month) on value-weighted stock market returns and Fama-French factors. Standard errors are in parentheses. For the overlapping three-month intervals, the standard errors are corrected using the Newey-West procedure. * denotes statistical significance at the $90 \%$ confidence level and $* *$ at the $95 \%$ confidence level. The data are quarterly from 1990 to 1993 and monthly from 1994 to 2003. 


\begin{tabular}{|c|c|c|c|c|}
\hline \multicolumn{5}{|c|}{$\begin{array}{l}\text { Table 6a: REIT NAV Returns Conditional on Absolute Level of P/NAV, } \\
\text { 01/1990 to } 12 / 2003 \\
\text { Dependent variable: value-weighted NAV return }\end{array}$} \\
\hline & \multicolumn{2}{|c|}{ One Month } & \multicolumn{2}{|c|}{ Three Month } \\
\hline & No FF & Include FF & No FF & Include FF \\
\hline Portfolio 1 & $(\mathrm{~N}=116)$ & $\mathrm{P} / \mathrm{NAV}<90 \%$ & & \\
\hline$\alpha$ & $\begin{array}{r}-0.0035 * \\
(0.0018)\end{array}$ & $\begin{array}{r}-0.0036 * \\
(0.0019)\end{array}$ & $\begin{array}{r}-0.0051 \\
(0.0053)\end{array}$ & $\begin{array}{r}-0.0070 \\
(0.0060)\end{array}$ \\
\hline$\beta$ & $\begin{array}{r}0.072 \\
(0.046)\end{array}$ & $\begin{array}{r}0.078 \\
(0.047)\end{array}$ & $\begin{array}{r}0.064 \\
(0.082)\end{array}$ & $\begin{array}{r}0.078 \\
(0.081)\end{array}$ \\
\hline SMB & & $\begin{array}{r}0.022 \\
(0.047)\end{array}$ & & $\begin{array}{r}0.074 \\
(0.059)\end{array}$ \\
\hline HML & & $\begin{array}{r}0.013 \\
(0.032) \\
\end{array}$ & & $\begin{array}{r}0.038 \\
(0.035) \\
\end{array}$ \\
\hline Portfolio 2 & $(\mathrm{~N}=134)$ & $90 \%<\mathrm{P} / \mathrm{NAV}<1$ & & \\
\hline$\alpha$ & $\begin{array}{r}-0.00011 \\
(0.0013)\end{array}$ & $\begin{array}{r}-0.00029 \\
(0.0013)\end{array}$ & $\begin{array}{r}0.0030 \\
(0.0042)\end{array}$ & $\begin{array}{r}0.0021 \\
(0.0044)\end{array}$ \\
\hline$\beta$ & $\begin{array}{l}0.12 * * \\
(0.031)\end{array}$ & $\begin{array}{l}0.11 * * \\
(0.031)\end{array}$ & $\begin{array}{l}0.13 * * \\
(0.036)\end{array}$ & $\begin{array}{l}0.12 * * \\
(0.033)\end{array}$ \\
\hline SMB & & $\begin{array}{r}0.053 \\
(0.037)\end{array}$ & & $\begin{array}{r}0.084 \\
(0.060)\end{array}$ \\
\hline HML & & $\begin{array}{r}-0.012 \\
(0.029)\end{array}$ & & $\begin{array}{r}0.0050 \\
(0.032)\end{array}$ \\
\hline Portfolio 3 & $(\mathrm{~N}=133)$ & $100 \%<\mathrm{P} / \mathrm{NAV}<$ & $0 \%$ & \\
\hline$\alpha$ & $\begin{array}{r}0.0056 * * \\
(0.0010)\end{array}$ & $\begin{array}{r}0.0056 * * \\
(0.0010)\end{array}$ & $\begin{array}{l}0.013 * * \\
(0.0045)\end{array}$ & $\begin{array}{l}0.012 * * \\
(0.0040)\end{array}$ \\
\hline$\beta$ & $\begin{array}{r}0.078 * * \\
(0.026)\end{array}$ & $\begin{array}{r}0.073 * * \\
(0.026)\end{array}$ & $\begin{array}{l}0.14 * * \\
(0.041)\end{array}$ & $\begin{array}{r}0.12 * * \\
(0.04)\end{array}$ \\
\hline SMB & & $\begin{array}{r}0.034 \\
(0.031)\end{array}$ & & $\begin{array}{r}0.10 \\
(0.063)\end{array}$ \\
\hline HML & & $\begin{array}{r}-0.016 \\
(0.030)\end{array}$ & & $\begin{array}{r}0.038 \\
(0.040) \\
\end{array}$ \\
\hline Portfolio 4 & $(\mathrm{~N}=128)$ & $\mathrm{P} / \mathrm{NAV}>110 \%$ & & \\
\hline$\alpha$ & $\begin{array}{r}0.013 * * \\
(0.0015)\end{array}$ & $\begin{array}{l}0.012 * * \\
(0.0015)\end{array}$ & $\begin{array}{l}0.031 * * \\
(0.0051)\end{array}$ & $\begin{array}{r}0.031 * * \\
(0.005)\end{array}$ \\
\hline$\beta$ & $\begin{array}{r}0.054 \\
(0.041)\end{array}$ & $\begin{array}{r}0.051 \\
(0.040)\end{array}$ & $\begin{array}{l}0.11 * * \\
(0.047)\end{array}$ & $\begin{array}{r}0.10 * \\
(0.053)\end{array}$ \\
\hline SMB & & $\begin{array}{l}0.13 * * \\
(0.045)\end{array}$ & & $\begin{array}{r}0.073 \\
(0.080)\end{array}$ \\
\hline HML & & $\begin{array}{r}0.028 \\
(0.052) \\
\end{array}$ & & $\begin{array}{r}0.080 \\
(0.059) \\
\end{array}$ \\
\hline
\end{tabular}

Each portfolio model is estimated separately using weighted-least squares (weight $=$ the number of REITs in the portfolio that month) on value-weighted stock market returns and Fama-French factors. Standard errors are in parentheses. For the overlapping three-month intervals, the standard errors are corrected using the Newey-West procedure. $*$ denotes statistical significance at the $90 \%$ confidence level and $* *$ at the $95 \%$ confidence level. The data are quarterly from 1990 to 1993 and monthly from 1994 to 2003. 


\begin{tabular}{|c|c|c|c|c|}
\hline \multicolumn{5}{|c|}{$\begin{array}{c}\text { Table 6b: Differential NAV Returns on Low Minus High Value R } \\
\text { to } 12 / 2003 \\
\text { Dependent Variable: value-weighted NAV return }\end{array}$} \\
\hline & \multicolumn{2}{|c|}{ One Month } & \multicolumn{2}{|c|}{ Three Month } \\
\hline & No FF & Include FF & No FF & Include FF \\
\hline Portfolio 1 & $\mathrm{P} / \mathrm{NAV}<90 \%$ & & & \\
\hline$\alpha$ & $\begin{array}{r}-0.0064 * * \\
(0.0021)\end{array}$ & $\begin{array}{r}-0.0066 * * \\
(0.0021)\end{array}$ & $\begin{array}{r}-0.013 * * \\
(0.0048)\end{array}$ & $\begin{array}{r}-0.017 * * \\
(0.0058)\end{array}$ \\
\hline$\beta$ & $\begin{array}{r}0.10 * \\
(0.055)\end{array}$ & $\begin{array}{r}0.10 * \\
(0.056)\end{array}$ & $\begin{array}{r}0.077 \\
(0.093)\end{array}$ & $\begin{array}{r}0.13 \\
(0.087)\end{array}$ \\
\hline SMB & & $\begin{array}{l}0.0034 \\
(0.064)\end{array}$ & & $\begin{array}{r}0.024 \\
(0.070)\end{array}$ \\
\hline HML & & $\begin{array}{r}0.028 \\
(0.043) \\
\end{array}$ & & $\begin{array}{l}0.12 * * \\
(0.061) \\
\end{array}$ \\
\hline Portfolio 4 & $\mathrm{P} / \mathrm{NAV}>110 \%$ & & & \\
\hline$\alpha$ & $\begin{array}{r}0.0082 * * \\
(0.0012)\end{array}$ & $\begin{array}{r}0.0081 * * \\
(0.0012)\end{array}$ & $\begin{array}{l}0.022 * * \\
(0.0037)\end{array}$ & $\begin{array}{l}0.022 * * \\
(0.0036)\end{array}$ \\
\hline$\beta$ & $\begin{array}{l}0.10 * * \\
(0.033)\end{array}$ & $\begin{array}{r}0.090 * * \\
(0.035)\end{array}$ & $\begin{array}{l}0.13 * * \\
(0.033)\end{array}$ & $\begin{array}{l}0.12 * * \\
(0.035)\end{array}$ \\
\hline SMB & & $\begin{array}{r}0.038 \\
(0.042)\end{array}$ & & $\begin{array}{r}0.042 \\
(0.079)\end{array}$ \\
\hline HML & & $\begin{array}{r}0.013 \\
(0.041)\end{array}$ & & $\begin{array}{r}0.046 \\
(0.052)\end{array}$ \\
\hline \multicolumn{5}{|c|}{ Portfolio 1 minus Portfolio 4} \\
\hline$\alpha$ & $\begin{array}{r}-0.015 * * \\
(0.0029)\end{array}$ & $\begin{array}{r}-0.015 * * \\
(0.0029)\end{array}$ & $\begin{array}{r}-0.036 * * \\
(0.0055)\end{array}$ & $\begin{array}{r}-0.038 * * \\
(0.0056)\end{array}$ \\
\hline$\beta$ & $\begin{array}{r}0.089 \\
(0.079)\end{array}$ & $\begin{array}{r}0.069 \\
(0.080)\end{array}$ & $\begin{array}{r}0.037 \\
(0.094)\end{array}$ & $\begin{array}{r}0.034 \\
(0.084)\end{array}$ \\
\hline SMB & & $\begin{array}{r}0.11 \\
(0.094)\end{array}$ & & $\begin{array}{r}0.11 \\
(0.094)\end{array}$ \\
\hline HML & & $\begin{array}{r}0.089 \\
(0.072)\end{array}$ & & $\begin{array}{r}0.14 * \\
(0.073)\end{array}$ \\
\hline
\end{tabular}

The regressions only include month-years with observations for both Portfolio 1 and Portfolio 4. $\mathrm{N}=108$ for one-month regressions; $\mathrm{N}=106$ for three-month regressions.

Each portfolio model is estimated separately using weighted-least squares (weight $=$ the number of REITs in the portfolio that month) on value-weighted stock market returns and Fama-French factors. Standard errors are in parentheses. For the overlapping three-month intervals, the standard errors are corrected using the Newey-West procedure. * denotes statistical significance at the $90 \%$ confidence level and $* *$ at the $95 \%$ confidence level. The data are quarterly from 1990 to 1993 and monthly from 1994 to 2003. 


\section{Figure 1}

Ratio of Price/Net Asset Value (P/NAV)

Sample is all REITs covered by Green Street Advisors 1994:01-2003:12

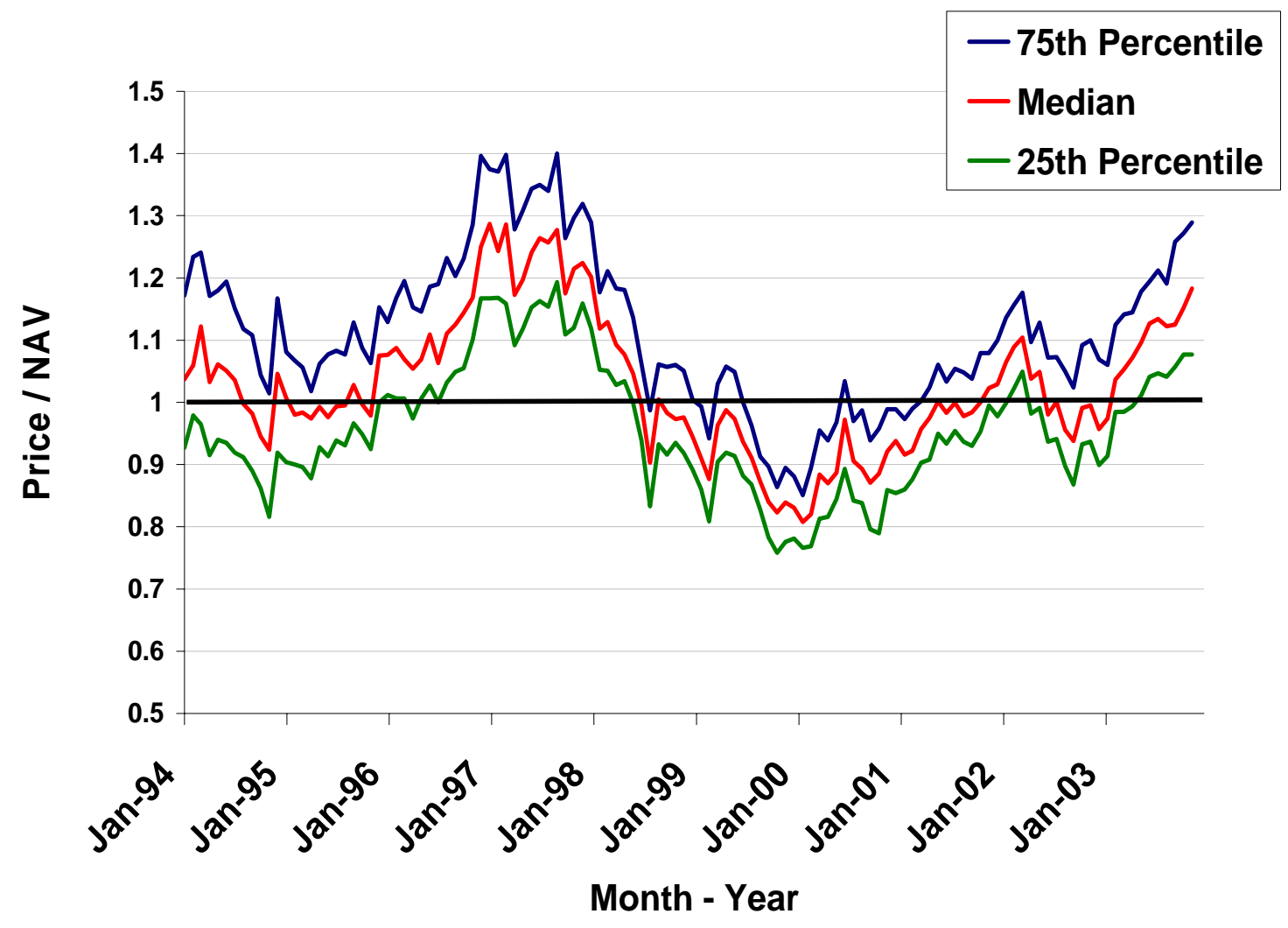




\section{Figure 2}

Cumulative Daily Returns

by Price/Net Asset Value (P/NAV) Quartiles

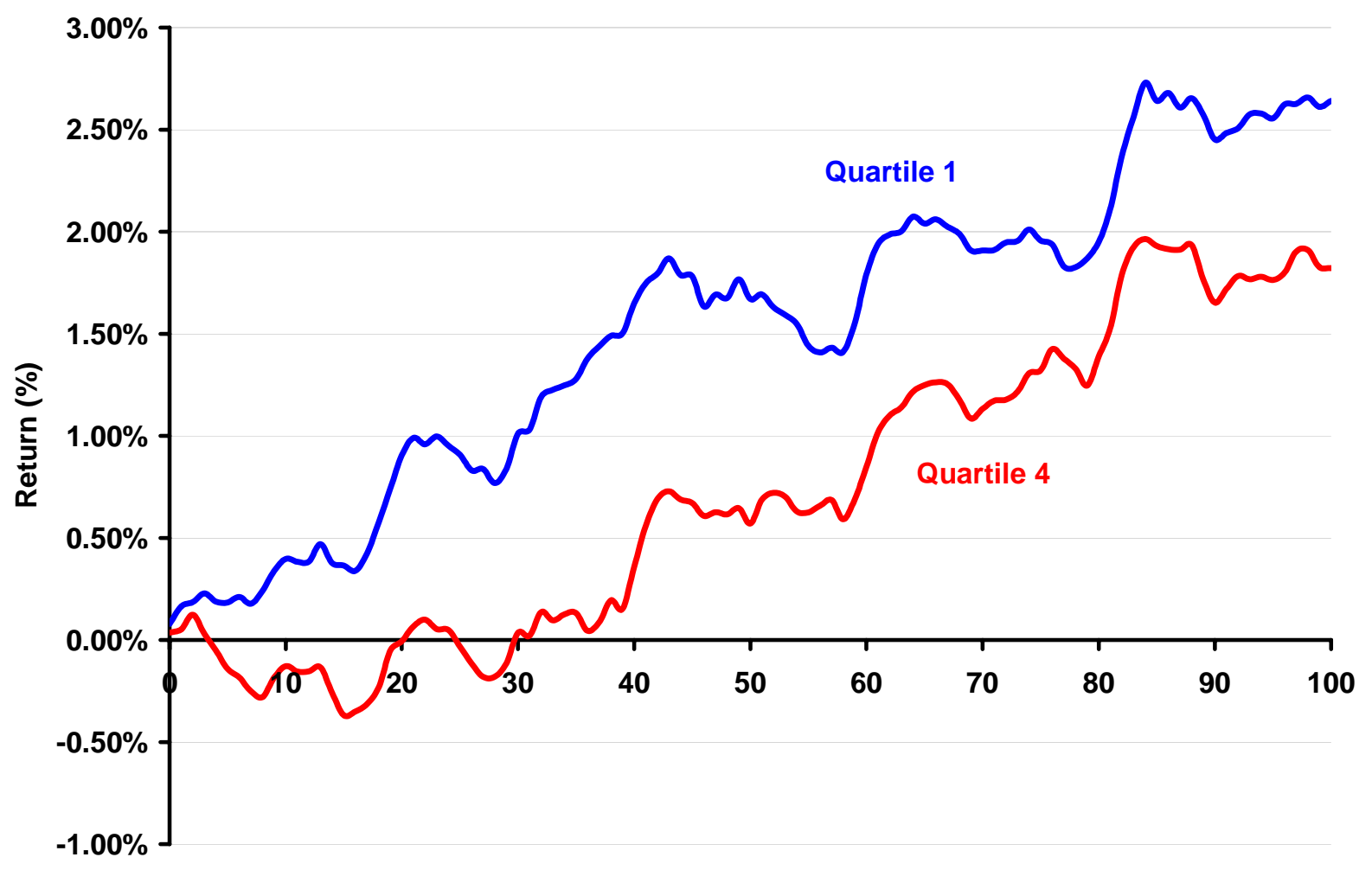

Day 


\section{Figure 3}

Difference Between Returns for Portfolio 1 minus Portfolio 4 Sample is all REITs covered by Green Street Advisors 1994:01-2003:12

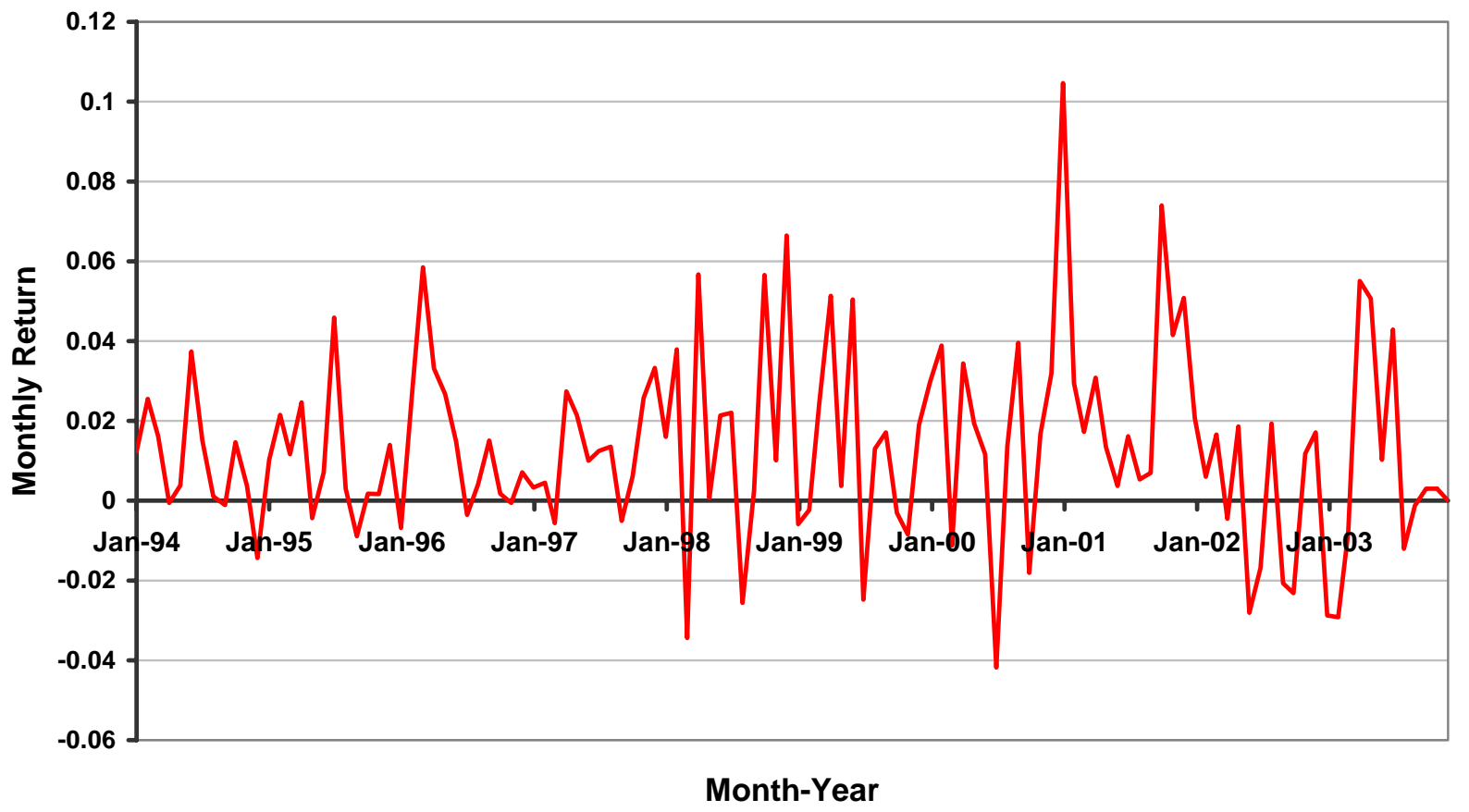

